
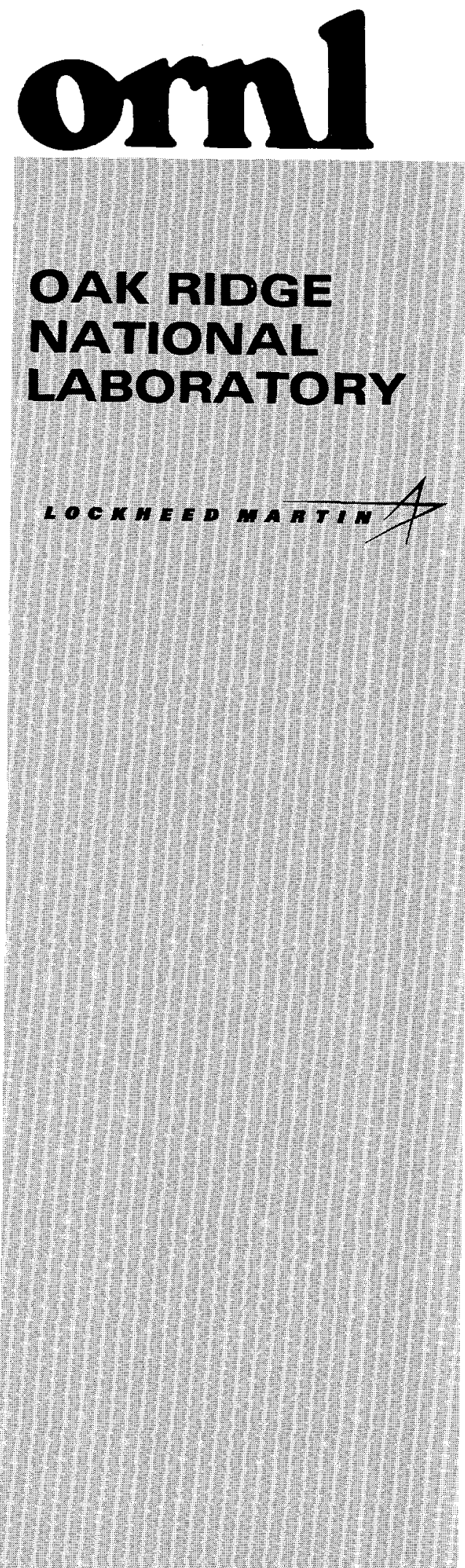

WANAGED AND OPERATED BY

LOCKHEED MARTIN ENERGY RESEARCH CORPORATION FOR THE UNIED STATES

DEPARTMENT OF ENERGY

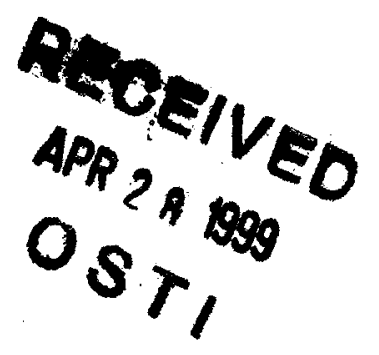

ORNL/TM-13722

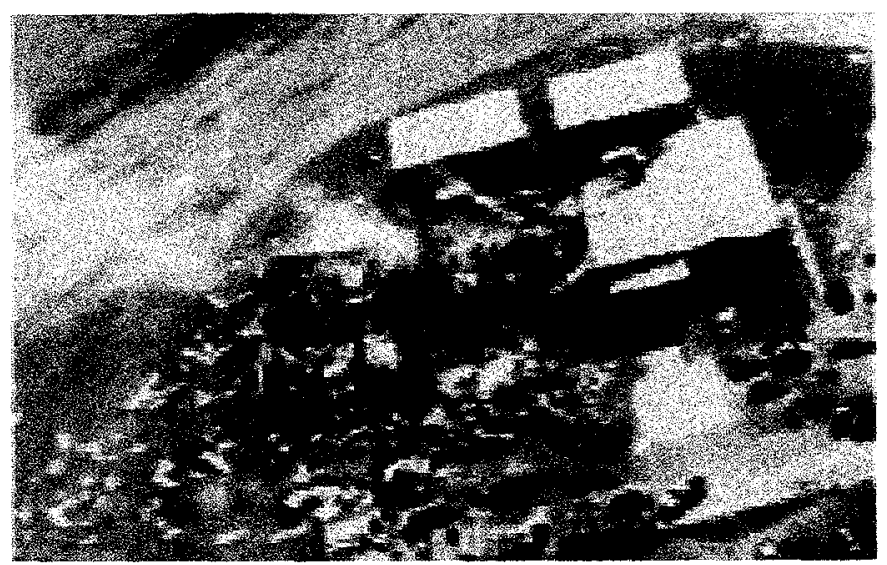

Barbara Muller Vogt John H. Sorensen 
This report has been reproduced directly from the best available copy.

Available to DOE and DOE contractors from the Office of Scientific and Technical Information, P. O. Box 62, Oak Ridge, TN 37831; prices available from (423) 576-8401, FTS 626-8401.

Available to the public from the National Technical Information Service, U.S. Department of Commerce, 4284 Port Royal Rd., Springfield, VA 22161.

This report was prepared as an account of work sponsored by an agency of the United States Government. Neither the United States

Government nor any agency thereof, nor any of their employees, makes any warranty, expressed or implied, or assumes any legal liability or responsibility for the accuracy, completeness, or usefulness of any information, apparatus, product, or process disclosed, or represents that its use would not infringe privately owned rights. Reference herein to any specific commercial product, process, or service by trade name, trademark, manufacturer, or otherwise, does not necessarily constitute or imply its endorsement, recommendation, or favoring by the United States Government or any agency thereof. The views and opinions of the authors expressed herein do not necessarily state or reflect those of the United States Government or any agency thereof. 


\section{DISCLAIMER}

Portions of this document may be illegible in electronic image products. Images are produced from the best available original document. 


\title{
DESCRIPTION OF SURVEY DATA REGARDING THE CHEMICAL REPACKAGING PLANT ACCIDENT WEST HELENA, ARKANSAS
}

\author{
Barbara Muller Vogt \\ John H. Sorensen
}

Date published-March 1999

Prepared for the

Federal Emergency Management Agency

\author{
Prepared by \\ OAK RIDGE NATIONAL LABORATORY \\ Oak Ridge, Tennessee 37831 \\ Managed by \\ LOCKHEED MARTIN ENERGY RESEARCH CORPORATION \\ For the \\ U.S. DEPARTMENT OF ENERGY \\ under contract No. DE-AC05-96OR22464
}




\section{TABLE OF CONTENTS}

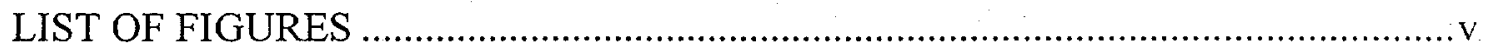

LIST OF TABLES

ACRONYMS AND ABBREVIATIONS .............................................................. vii

ABSTRACT

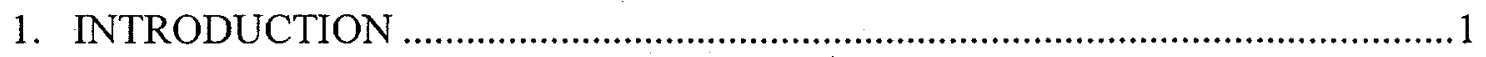

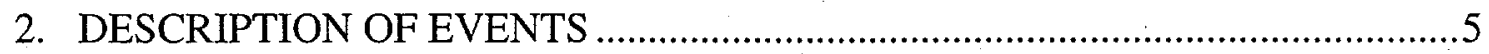

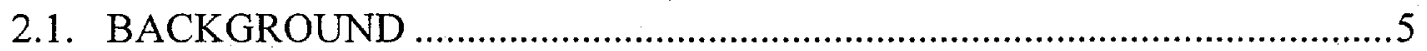

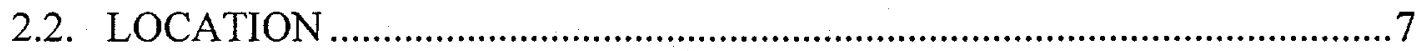

2.3. POPULATION CHARACTERISTICS …….......................................

2.4. DESCRIPTION OF CAUSE OF INCIDENT …….....................................

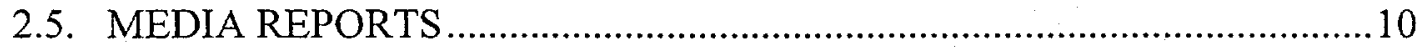

2.6. HOSPITAL EVACUATION …………..................................................... 11

3. DATA COLLECTION AND METHODOLOGY .................................................

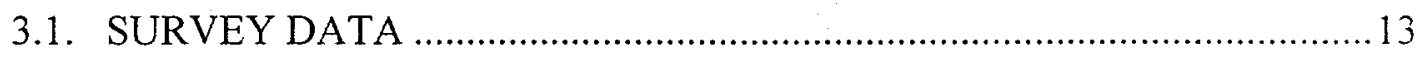

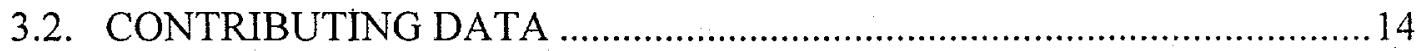

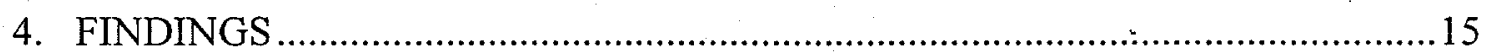

4.1. RESIDENTIAL CHARACTERISTICS AND KNOWLEDGE

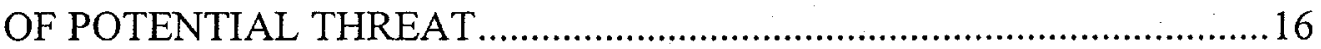

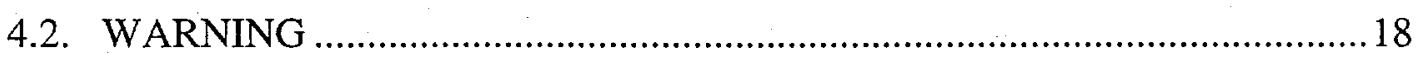

4.2.1. Warning Source ............................................................................ 18

4.2.2. Time of Receipt of Warning ............................................................. 19

4.2.3. Threat Perception .................................................................................2

4.2.4. Warning Belief and Content ..............................................................22

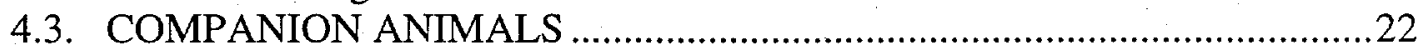

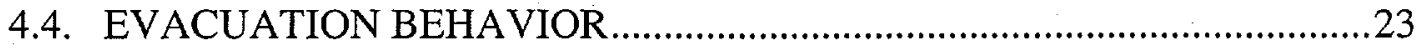

4.5. SHELTERING-IN-PLACE BEHAVIOR ………….................................24

4.6. PERCEPTIONS OF DANGER DURING EVENT .....................................25

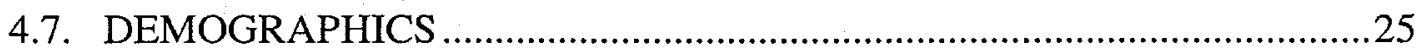

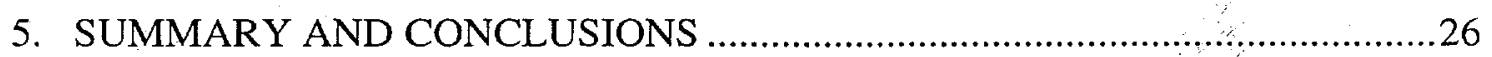

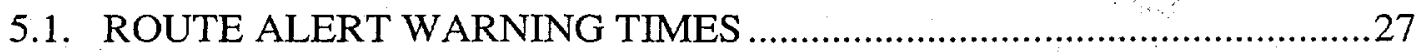

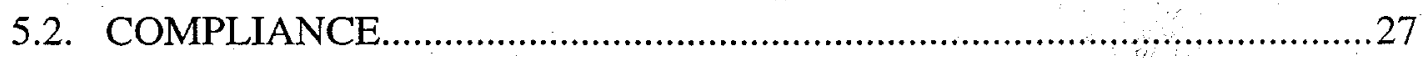

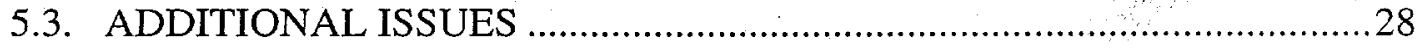

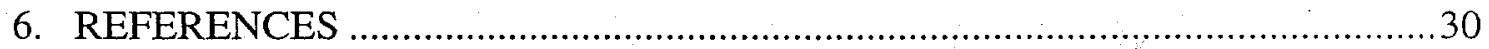



APPENDIX A: VIEW OF PLANT AT TIME OF EXPLOSION AND REBUILT FACILITY; VIEW OF RESIDENCES CLOSE TO PLANT; VIEW OF REGIONAL MEDICAL CENTER

APPENDIX B: COPY OF QUESTIONNAIRE AND

INTRODUCTORY LETTER

APPENDIX C: COPY OF LETTER REPORT SENT TO

RESPONDENTS 


\section{LIST OF FIGURES}

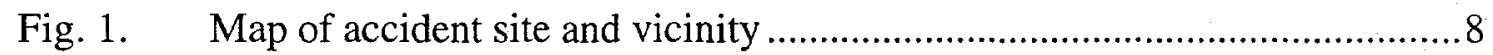

Fig. 2. Map depicting areas evacuated and those that sheltered .........................17

Fig. 3. When were people warned? ..................................................................20

Fig. 4. When respondents evacuated compared to when respondents reported receiving first warning (in minutes)..........................................................21

\section{LIST OF TABLES}

Table 1. Distance in miles of residence from repackaging facility ..........................16

Table 2. Type of residence as reported by respondent..............................................18

Table 3. Source of first warning as reported by respondents.....................................19

Table 4. Respondents' perception of source of information during event................19

Table 5. Reported perception of threat from stored chemicals before accident .......21

Table 6. Respondents' reported belief in warning ..................................................22

Table 7. Reported care of evacuee's companion animals..........................................23

Table 8. Destination sites as reported by evacuees..................................................23

Table 9. Availability (respondents could indicate more than one) ….....................24

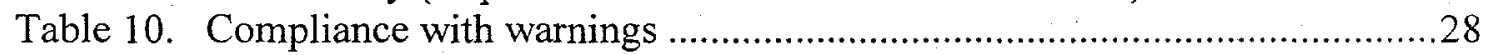





\section{ACRONYMS AND ABBREVIATIONS}

EPA

$\mathrm{H}_{2} \mathrm{~S}$

MSDSS

OES

RUP

U.S. Environmental Protection Agency

hydrogen sulfide

Material Safety Data Sheets

Office of Emergency Services

Restricted Use Pesticide 



\begin{abstract}
Shortly after 1:00 p.m. on Thursday, May 8, 1997, clouds of foul-smelling smoke began pouring from an herbicide and pesticide packaging plant in West Helena, Arkansas. An alert was sounded, employees evacuated, and the West Helena fire department was called. As three firefighters prepared to enter the plant, the chemical compounds exploded, collapsing a solid concrete block wall, and killing all three firefighters. As the odorous smoky cloud drifted away from the plant, authorities ordered residents in a 2-mile area downwind of the plant to evacuate and those in the 2- to 3-mile zone to shelter in place. This study examines and compares the responses to a mail survey of those ordered to evacuate and those told to shelter in place. Among the variables examined are compliance with official orders and perceived warnings, threat perception, time and source of first warning, response times, and behavior characteristics for both populations. The findings indicate that $90 \%$ of those that were told to evacuate did so but only $27 \%$ of those told to shelter-in-place did so, with $68 \%$ opting to evacuate instead. The implications of these findings for emergency managers is that people will likely choose to evacuate when both warnings to evacuate and warnings to shelter are issued to residents in close proximity to each other. The findings on warning times closely resemble other findings from evacuations when chemical accidents occur and route notification is used for warning residents.
\end{abstract}




\section{INTRODUCTION}

Emergency responders often have limited options and short timeframes for protecting the public in chemical accidents. Thus a chemical accident that releases toxic fumes frequently involves a evacuation of the affected areas of the community as a precautionary measure; but ensuring that all citizens are out of an evacuation zone, especially if the release is extremely toxic or presents secondary contamination issues, can be challenging.

The term "evacuation" is used to describe the temporary withdrawal actions of persons from a specific area because of a real or anticipated threat or hazard (Vogt and Sorensen 1992) and generally involves a round-trip movement (Quarantelli 1980). "Evacuation by default" may also occur when residents who are not at home at the time of the event are denied access to their homes and thus do not make the complete roundtrip (Drabek 1986). Evacuation generally refers to behavior prior to impact, although other possibilities exist, such as the occurrence of catastrophic events that permanently prevent residents from returning home (Perry, Lindell, and Greene 1981; Drabek 1986). Furthermore, not all residents will leave when an evacuation order is issued, and emergency responders can be placed in severe jeopardy if those residents become trapped and require rescue.

Although evacuation is the most common strategy used by emergency managers to protect the public, some authorities are now suggesting that sheltering in place or advised with evacuation may be a practical alternative for certain events where advance warning is not possible or for events that recur on a periodic basis. Vertical evacuation has been used in coastal areas with large transient populations who would have difficulty leaving the area at risk. When Hurricane Iniki hit Kauai, Hawaii, for example, evacuation off island was almost impossible given the extremely large number of tourists involved (Drabek 1996). Some researchers have suggested that the use of vertical shelters in place for hurricanes, especially if structurally safe buildings are available, would reduce the need for extended warning times (Salmon 1984).

Physically moving from an area exposed to a chemical hazard in the appropriate time frame may not be a viable option for certain vulnerable populations such as those in institutional settings, the elderly who need longer preparation time, people with special medical needs, or those with limited mobility or without vehicles who must rely on others for assistance. Both emergency measures-evacuation or sheltering - require accurate technical information (such as source term, meteorological conditions, and number of people in area at risk) as well as knowledge of the affected community's characteristics (such as availability of shelters or general housing conditions). In a crisis with short forewarning, such information may be delayed, unavailable, or not accounted for in the chaotic decision-making phase.

Reducing the risk from a toxic plume by staying inside (in-place sheltering) is not a new emergency management concept . However, there have been very few scientific studies or data to support sheltering in place over evacuation, or to indicate which action is best given a situation and which risks are associated with either action. Moreover, the empirical data gathered from hurricane studies on people that sheltered cannot be used to 
generalize to actions people would take in a chemical accident because both the time frame and potential risk from threat radically differ.

Most Americans are unfamiliar with expedient or enhanced shelter-in-place procedures because sheltering is generally not an option for natural hazards such as floods, volcanic eruptions, or wildfires. Tornadoes require a special type of sheltering - such as entering a below-ground structures or basement-that would be inappropriate for some chemical hazards (e.g., a chlorine spill) where fumes tend to sink or collect in low areas. Some foreign countries, most noticeably Israel, have encouraged in-place sheltering coupled with personal respiratory protection for potential chemical releases during warfare. Although respiratory protection is routinely used by hazardous materials teams, the required training and the physical stress would limit citizen use. At least two U.S. companies are now marketing respiratory devices designed for the general public, but how and when citizens would be expected to use those devices is unclear.

Empirical data are lacking on how people respond to shelter in place warnings, especially when people are told to evacuate in one area geographically adjacent to (in some cases, across the street from) another area told to shelter in place. Most studies of compliance with warnings have focused on orders to evacuate, but little research has been conducted on compliance with other protective action alternatives, such as shelter in place or temporary sheltering followed by evacuation (Sorensen 1992). Although sheltering in enhanced shelters was advocated by civil defense authorities for potential radiological emergencies during the Cold War period, the lack of actual events precluded investigating people's behavior given a warning to shelter in place. Moreover, the data from sheltering in radiological events would not be an appropriate comparison because of the very different time frame from most chemical releases.

When advising people to shelter in place, authorities must be certain that sheltering in residences or designated structures provides sufficient protection to residents. Normal sheltering in place actions generally involves little more than persons remaining inside a structure until an all-clear signal has been received. To ensure that indoor concentrations and toxic loads remain lower than the expected outdoor levels during the plume passage, occupants are instructed to close doors and windows and shut off heating or cooling systems that draw outside air into the structure before the plume arrives. Because of the build-up of potentially toxic fumes within a structure, it is equally important that residents know when to emerge from the dwellings and to vent the residence thoroughly after the plume has passed.

Thus, sheltering-in-place in one's residence may be an alternative if the toxic plume is fast moving or uncertain in direction or if evacuees may have to travel through the plume to reach a safe destination. Sheltering is also an option if emergency managers can assume that elements such as weatherization have been added to residences, thereby increasing shelter effectiveness. Weatherization to control air leakage (e.g., caulking, weather-stripping, insulating attics, adding storm windows and doors) has been shown to improve heating and cooling efficiency by decreasing air infiltration (Brown et al. 1993). A Canadian study involving simulation modeling of releases of hydrogen sulfide $\left(\mathrm{H}_{2} \mathrm{~S}\right)$ found that in all release situations investigated in residential structures, the indoor concentrations and toxic loads were significantly lower than the expected outdoor levels (Alberta Public Safety Services 1992). The study concluded that in cases where sufficient advance notice was not possible, people could effectively shelter indoors during periods 
of short releases of $\mathrm{H}_{2} \mathrm{~S}$. It should be noted that this was a Canadian study where weatherization would likely be expected in most dwellings.

"Expedient sheltering" is similar to normal shelter-in-place in that residents shelter within an indoor room of a structure. To further reduce outside air from infiltrating prior to the plume passage, residents are expected to shut down heat and ventilation systems, place towels along door edges, and use tape or other household products to seal seams and other openings of the room used as shelter. Once the plume is past, residents will have to ventilate or abandon the structure to prevent further exposure from contaminated air that may have infiltrated during the plume passage. Thus emergency officials who advise residents to protect themselves with this type of sheltering must also have the means to communicate with them after the plume passes. Although most actions can be implemented quickly by residents, expedient sheltering provides only moderate protection during plumes of short duration (Rogers et al. 1990).

"Enhanced sheltering" involves taking protective shelter in structures that have reduced infiltration rates because of existing weatherization techniques. Enhanced sheltering also requires residents to close windows and doors, shut off heating and ventilation systems and to vent or abandon the structure after the plume has passed. Again, warnings systems must include the means to advise people when to vent their structures. Enhanced sheltering provides better protection than normal sheltering under plumes of moderate size and limited duration.

"Pressurized sheltering" describes sheltering in buildings equipped with filtered air venting systems that over-pressurize internal spaces and keep external contaminated air from entering the structure. Hospitals may use this type of enhancement to protect vulnerable patients who cannot be moved or delicate equipment during emergencies. Some schools located near hazardous facilities have provided certain congregation areas (such as cafeterias or auditoriums) with enhanced sheltering measures, thereby decreasing their potential exposure to contaminants.

"Specialized sheltering" involves taking refuge in commercial tents or structures designed for the collective protection of groups from toxic chemical exposures (Rogers et al. 1990). The specialized facilities provide maximum protection under almost all conditions, including slow moving plumes. However, the facilities must be built and prepositioned prior to the event and require special precautions to prevent breach of the containment once occupants are inside (Sorensen 1988).

The decision to order an evacuation involves several factors and is often related to political factors as well as geographical or other physical boundaries. Local emergency planners and officials must first decide if residents have sufficient time to prepare and leave before the toxic plume arrives. Traditionally, when people evacuated, they commonly did so in groups, most generally as family units (Drabek 1983, 1986). Delays while family members were contacted or accounted for elsewhere were usual (Drabek 1986; Perry, Lindell, and Greene 1981). Thus unless the event requires immediate action - such as when a fire, tornado, or flash flood occurs - people tend to gather up belongings and wait for or account for other family members before leaving. This delay must be accounted for in emergency management. For maximum protection in toxic chemical releases, it is equally important that evacuees not be traveling through the plume in their vehicles and have sufficient time to reach a safe destination. Moreover, a vehicle offers far less protection than most closed residential structures, with most 
vehicles having seven air changes per hour as opposed to the four air changes per hour for residential dwellings.

In this study official advisories to evacuate or shelter-in-place were extended to different segments of the community based on the approximate distance of the residence from the accident site. The boundaries generally conformed to street or highways and were extended as the toxic cloud changed direction as a result of wind shifts. Residents within 2 miles downwind of the accident site were told to evacuate, while residents between 2 and 3 miles were told to go inside and shelter-in-place.

The resulting actions presented an opportunity to study whether those told to evacuate left their residences as told, sheltered, or did something else and whether those told to shelter actually sheltered, evacuated instead, or did something else. In this study, some residents did not evacuate or shelter immediately as they were out of the area at the first warning and were denied access to their residences on returning home. One family with a bedridden family member requested official help to enter the evacuation zone to evacuate the elderly woman as well as her caretaker from their residence.

Information on behavior was obtained from a mail survey of residents in areas officially told to evacuate and those that were told to shelter. Sixty-four percent of the surveys sent to residents in these areas were returned. The study found that evacuation was the primary response in both groups. The questionnaires were designed to gather information on when and how people received warnings, what environmental clues were present, how long it took them to respond, where they went, what they did with companion animals, how long they stayed away or sheltered, and what actions they took after the event was over.

By providing some empirical indication of how those affected by the event responded to the evacuation or shelter-in-place orders, the information gained from the respondents to the survey contributes to the overall data on sociological behavior of persons faced with a real chemical threat. This report presents a descriptive summary and a univariate analysis of the variables measured. Many of the questions on the survey duplicate those from other published surveys and thus provide some format for comparison to other behavior during extreme events. However, the report is not intended to provide an explanatory analysis of the interrelationships among the variables measured. As such, the report represents only an initial analysis of the responses. Further analysis, as well as comparison to other such studies, is needed to provide a complete understanding to aid emergency managers in predicting the public's response to official evacuation or shelter-in-place orders.

Section 2 of this report describes the event and the background elements to place the responses in context, and Sect. 3 describes the methods used to collect data using a mail survey to affected residents. Section 4 presents the findings, focusing on the response to the official orders, the respondents perception of the official orders, and the actions respondents took or did not take. Section 5 summarizes what was learned and offers some initial conclusions as to the implications for emergency planners and managers. 


\section{DESCRIPTION OF EVENTS}

This section describes the location of the facility where the fire and explosion occurred, the sequence of events that resulted in the release of a toxic plume, the properties of the chemical involved, and the demographic and other socioeconomic characteristics of the general population affected by the event. Media reports and eyewitness accounts of the event are also examined to help clarify the social behavior dimensions and dynamics of the situation.

\subsection{BACKGROUND}

The herbicide and pesticide chemical repackaging facility where the accident occurred is located in an industrial park in West Helena, Arkansas. The industrial park adjoins a railroad track spur and is the site of a number of other chemical and manufacturing industries. As is typical of many rural communities, the industrial park is located away from the town, in this case amidst fields of rice and cotton. The plant itself occupies two industrial-style, metal-fabricated buildings separated by a single lane road.

Adjacent to the buildings are parking lots and staging areas, mostly unpaved. The facility itself does not manufacture products; it receives bulk chemicals and repackages them for local and regional agricultural use. Much of the plant work is seasonal, depending on agricultural needs in the area. In May the facility was at peak production.

The incident began at approximately 10:00 a.m. on Thursday, May 8, 1997, when some agricultural chemicals were delivered to the plant. Workers recall that one of the $1500-1 \mathrm{~b}$ bulk containers of azinphos-methyl had a strange, almost rancid, odor when delivered to the plant. The container, double wrapped in disposable heavy duty plastic, was brought into the plant where, several hours later, it started to emit fumes. As the fumes spread from the container, creating a smoky haze, plant employees evacuated to the parking lot of the building across the street; and managers conducted a head count to make sure all employees were out of the building. A supervisor then attempted to remove the container with a forklift but failed because the fumes-even with two 24,000$\mathrm{ft}^{3} / \mathrm{min}$ fans moving air out of the building-were too thick. Witnesses recall two layers of smoke, the lower layer a smoky gray and the upper layer a smoky yellow.

The cause of the reaction within the container was unclear to management because the azinphos-methyl was declared to have zero reactivity and zero flammability by the manufacturer. Thinking the problem could have been heat emitted from a nearby compressor, the utility company was called to shut off the building's power source-a three-wire relay. When the first wire was cut, all systems, including the fans venting the structure, were shut down. It is thought that when the second cut was made, an arc occurred that ignited particulates in the smoke, causing the explosion. However, the exact cause of the explosion may never be known, even though the manufacturer immediately sent four experts (arriving at 6:00 p.m. that night) to the scene to help determine the cause (Bartlo 1998).

About 1:10 p.m., firefighters were notified of the event and immediately responded to the scene. At approximately 1:30, the explosion occurred, collapsing an 
exterior concrete wall and killing three firefighters. Built to withstand earthquakes in this seismically active area, the building's concrete block walls-reinforced to withstand lateral movement - had fallen in one slab outward from the interior explosion onto the emergency responders. Without support, the metal roof also collapsed over the building's contents. At the time, an estimated 100,000 lb of different types of chemicals and an undetermined amount of highly combustible packaging materials were stored in the building.

The deaths of the two professional and one volunteer firefighters devastated the small West Helena fire department, and the operational command was taken over by the Helena Fire Department which had responded as operational backup to the local force. Although the Helena firefighting unit was not equipped to respond to a chemical emergency, a decision was made to try a rescue attempt wearing available equipment. After the deaths were confirmed, the firefighters moved back and discontinued further rescue attempts. With fire equipment unable to reach the burning materials because of the collapsed roof, the fire continued to rage, releasing thick smoke plumes and fumes that moved from the park over adjacent communities.

Other companies in the industrial park-many of them operating chemical plants-ceased operations as a precautionary measure. Officials first secured the perimeter of the repackaging plant but as the fire continued, the entire industrial park was closed. As acrid clouds of foul-smelling smoke poured from the fire scene, authorities sounded the two community tornado alert sirens and began advising residents in a 2 -mile area downwind of the industrial park to evacuate. Residents in the 2- to 3-mile zone from the plant were told to shelter in place. As the cloud spread, officials closed the main roads around the industrial park and deputies went door to door in the evacuation zone telling people to leave the area. Radio broadcasts repeated the instructions from the Phillips County Office of Emergency Services (OES) to evacuate or to shelter-in-place. Some residents left the area on their own before receiving any warning as smoke and fumes poured over their homes.

The characteristics of the chemicals stored in the plant and the collapsed roof made the fire extremely difficult to extinguish. As the dense clouds drifted toward the Mississippi River, Coast Guard officials closed portions of the river to barge traffic as a precaution. A regional medical center close to the initial evacuation zone also evacuated their personnel to a local community college. Some patients were transferred to an area nursing home, with the more critically ill patients transferred to a Mississippi hospital a half hour away. Patients that could be discharged home were accompanied by a hospital employee. One woman in labor was transferred to the community college where physicians could monitor her progress. The community college has a nursing program with three equipped rooms used for training. The medical center would reopen the evacuated facility 6 days later after thoroughly decontaminating the facility and being given a State Board of Health certified approval.

As news of the event spread throughout media reports, the governor of Arkansas arrived and stocks of atropine were brought from a military installation in Pine Bluff, Arkansas. The Army stores the antidote for organphosphate chemical exposure at the installation in case of an accidental release of chemical warfare agents from the installation's stockpile. Reportedly, no atropine was needed in the Helena incident because no confirmed exposure of residents occurred. At 10:00 p.m. road barriers were 
removed and residents were allowed to return to their homes. The sporadic fires that occurred through the next few days did not result in any subsequent evacuations, although officials considered doing so many times.

\subsection{LOCATION}

Figure 1 presents a map of the area and displays the streets in the 2-and 3-mile radii within which residents were told to evacuate or shelter-in-place by officials. The Helena-West Helena community of 17,186 people is located in Phillips County, Arkansas, which adjoins the Mississippi River. The Mississippi Bridge, one of only six bridges that cross the Mississippi River between Memphis and New Orleans, connects the city of Helena with Memphis, via U.S. Highway 61, approximately an hour's drive away. Although most of the area is rural and population density is low, Philips County has a modern industrial park (where the chemical repackaging plant was located) with both railroad and highway accessibility.

Phillips County is located in one of the America's richest agricultural areas, known as the Arkansas Delta. Operating historically on a "plantation" system that capitalized on labor provided by slaves and sharecroppers, Delta agriculture was for a long time a rich land with poor people. Today the consolidation of lands and technology has made agriculture in the Arkansas Delta big business but has not significantly increased income levels. Eighty-one percent of the land in Phillips County is currently farmed (Bureau of the Census 1992). Even though the number of small- and moderatesized farms has decreased since 1978, the overall farmed acreage in the county has remained fairly constant. Soybeans, rice, cotton, wheat, fruits, vegetables, and livestock are mainstays of the local economy. The most recent agricultural estimates indicate soybeans and cotton are the two largest grown commodities, constituting $74 \%$ of the 357,416 acres farmed (Agricultural Census for Phillips County 1992).

\subsection{POPULATION CHARACTERISTICS}

Although rich in agricultural resources, the population of Phillips County has steadily declined as machine farming displaced agricultural workers. During World War II, the region lost almost $20 \%$ of its population. Census figures indicate 34,830 people lived in Phillips County in 1980, but in 1995 the population had decreased to 27,386, primarily because of the number of Blacks and Whites out-migrating. In 1990 slightly less than one-half (43\%) of Phillips County residents lived below the poverty level as compared with the state average of $19.6 \%$ living below poverty. The county also exceeds the national average for the percentage of residents living in poverty and persons over age 65 . The only Arkansas county with a higher level of persons living below poverty is neighboring Lee County, with $47.3 \%$.

Racial characteristics of the population within Phillips County also differ markedly from the State of Arkansas. More than one-half of Phillips County residents are Black (54.6\%) as compared to the state average of $16 \%$ (Bureau of the Census 1990). The number of persons over $65(14.1 \%)$ in Phillips County, however, approximates that of the State 


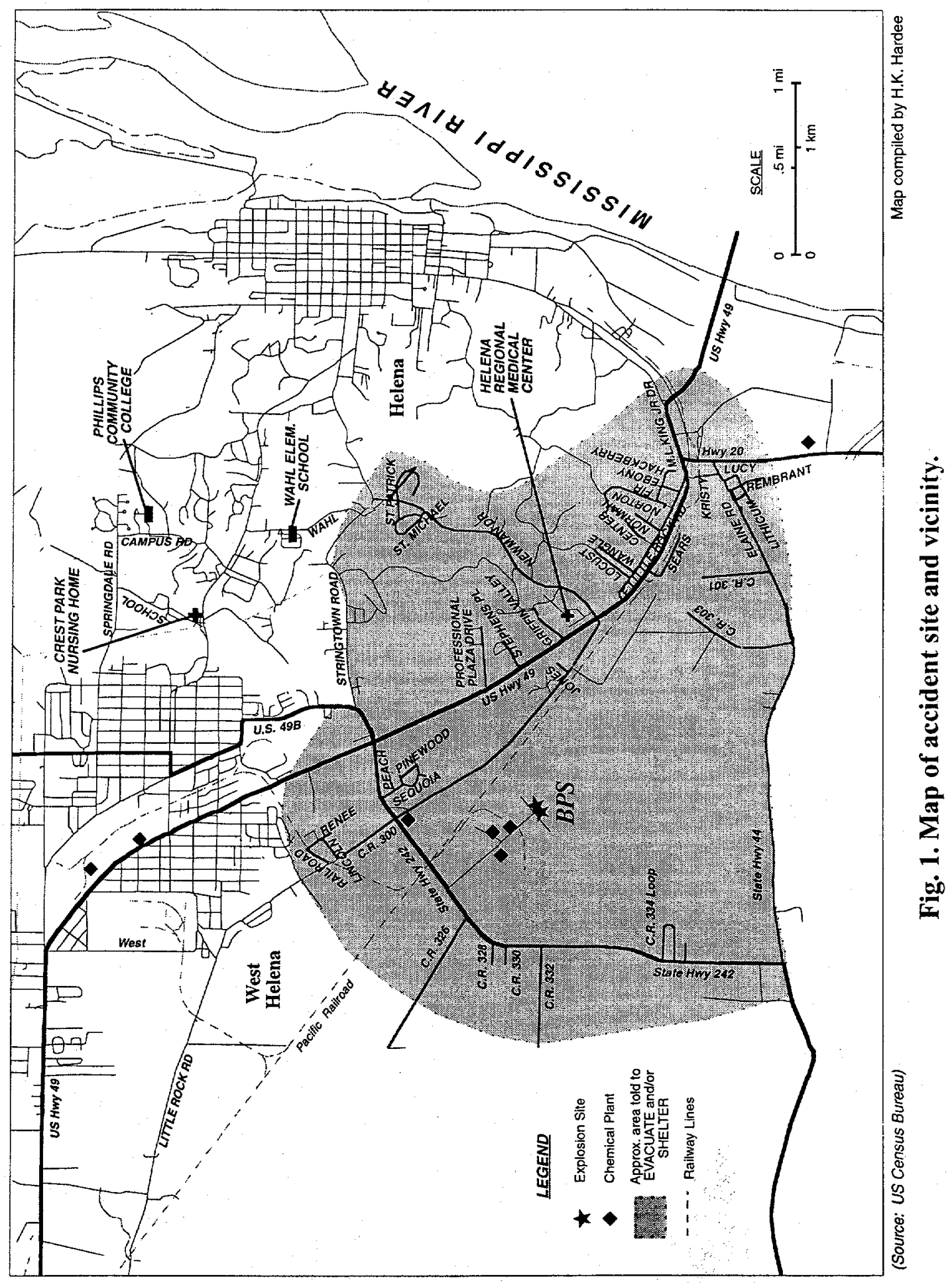


of Arkansas (14.77\%). Arkansas is below the national average for median household income and educational attainment (Bureau of the Census 1996).

\subsection{DESCRIPTION OF CAUSE OF INCIDENT}

As many as eight different chemical compounds were stored in the building at the time of the explosion, but azinphos-methyl, a highly persistent insecticide that attacks the central nervous system, was the one identified as causing the original explosion. Azinphos-methyl is a broad-spectrum, organophosphorus insecticide that was first produced in 1953 and is used solely for agricultural purposes (New York State Dept. of

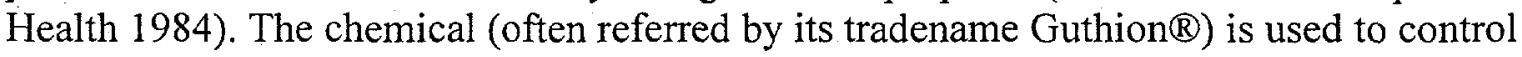
mites and other insects on citrus, cotton, grapes, maize, fruits and vegetables. The chemical, with characteristics similar to the chemical warfare nerve agent Sarin, is on the U.S. Environmental Protection Agency's (EPA's) restricted use list. The EPA has imposed a 24 -h reentry interval for this material. Areas that have been treated with azinphos-methyl may not be reentered for at least $24 \mathrm{~h}$, unless protective clothing is worn. Products containing azinphos-methyl must bear the signal words "Danger" and "Poison."

The Pesticide Information Notebook, a Web-based information source called EXTOXNET and supported by the Pesticide Management Education Program at Cornell University, reports

Pure azinphos-methyl is a white-crystalline solid. Technical azinphos-methyl is a brown waxy solid (EPA 1986). Azinphosmethyl is chemically stable under normal temperatures and pressures, and can be stored under ordinary conditions for an unlimited period of time. However, high temperatures may cause gas evolution and the development of pressure in enclosed containers. Azinphos-methyl is unstable above 200 degrees C. It poses a negligible fire hazard when exposed to heat or flame, but poses a fire and explosion hazard in the presence of strong oxidizers. It may hydrolyze in the presence of acids or alkalis. Thermal decomposition of azinphos-methyl may release toxic oxides of nitrogen, phosphorus, sulfur and carbon (Occupational Health Services, Inc. 1991).

Azinphos-methyl is one of the most toxic of the organophosphate insecticides, especially for children, by all exposure routes-inhalation, dermal absorption, ingestion, and eye contact. Like other organophosphate substances, azinphos-methyl is referred to as a "cholinesterase inhibitor." It binds up, blocks, or damages, the normal functioning of cholinesterase, an enzyme essential to the proper working of the nervous system. All azinphos-methyl liquids with a concentration greater than $13.5 \%$ are classified as Restricted Use Pesticides (RUP) by EPA because of the human inhalation hazard and acute toxicity presented by the material, as well as its potential adverse effects to other 
mammals, birds, and aquatic organisms. RUPs may be purchased and used only by certified applicators.

\subsection{MEDIA REPORTS}

Representatives of the media quickly converged on the accident site. Helicopters with media personnel flew over the site, reporting the event as national news and even posting a video sequence of the burning building on the Internet. In some cases, helicopters allowed firefighters to reconnoiter the accident scene from the air. As the clouds continued and fears for safety increased, local authorities advised closing the air space above the plant to minimize the chances of accidents. The closure resulted in the local airport being closed as well. Media reports went on-line to describe the number of businesses and government offices being closed in Helena to allow employees to pick up schoolchildren, how downwind subdivisions and houses were being evacuated, and what portions of roads were closed.

Some inaccurate or unconfirmed media reports failed to be corrected in later reports. One media report on the evacuated medical facility described patients being taken to local community colleges or to an elementary school and the most seriously ill patients being taken to local nursing homes or to a hospital in Clarksdale, Mississippi, a half-hour away. In reality, most patients were discharged home accompanied with hospital staff, others were taken to a wing of a local nursing home with hospital staff as support, and only a few seriously ill patients were taken to the Mississippi hospital. One media report was delivered from the steps of the evacuated hospital, telling viewers the hospital emergency room remained open. The problem was that the report failed to mention that the emergency room had been moved to the community college a few miles away, which confused persons arriving at the evacuated hospital.

Media reports also indicated that when the wind changed directions, students from both the elementary school and high school were evacuated to a junior high school in West Helena. Some students whose houses were north of Springtown Road were allowed to go home early. All the students who lived in areas south of that line had to stay at the

junior high because their homes were in the off-limits areas. The media also reported that some parents who picked up schoolchildren were unable to return home, a rumor which was never confirmed.

Other media sources reported restaurants and other downtown businesses closing and that employees of City Hall and the Phillips County Courthouse were sent home. The Phillips County OES is located in the basement of the courthouse and remained on full alert and working throughout the entire incident. One report noted that officials were "telling everyone to go in your home, close all your doors and windows and turn off air conditioners." The OES reported that this hampered their communications because people then called their office to find out when they could open their residences up again. Supposedly "closed" restaurants continued to prepare food for patrons as well as send food to emergency workers at the site.

The media kept close tabs on meteorological conditions. At one point, the media noted, the wind was blowing the toxic smoke in the direction of downtown but that it later "turned away from the city." As the fire continued, officials reportedly scurried to 
find respirators for police officers working near the burning plant. The lack of protective equipment for emergency responders is in the process of being remedied with a substantial investment from the company who had the accident as well as from other corporate sponsors. The media reported four residents being taken to the Phillips County Community College with respiratory problems but hospital reports indicate that only one firefighter had severe respiratory problems, largely as a result of heat exhaustion and stress involved in actually fighting the fire.

The media's attention to the accident did not go unnoticed by state politicians. Late in the day, the Arkansas Governor traveled from Little Rock to Phillips County to survey the damage. Media personnel reported his plane bringing air monitors and 1,100 units of atropine- "enough to treat 3,000-5,000 people"-as an antidote for people having respiratory problems from the accident. The media reports of the hospital having the "antidote" encouraged several persons to visit the evacuated hospital to request the "shot." At the same time EPA and military personnel from the army installation at Pine Bluff monitored exposure levels for the chemicals.

Media reports on the number of people evacuated were more accurate. The media reported that at 10:00 p.m. Thursday night the more than 300 evacuees were allowed to return to their residences. The 911 records indicate that approximately 364 persons were located in areas told to evacuate and the areas told to shelter. What was not communicated to the public by either the media or the authorities was that the fires continued to burn in some areas of the plant and would continue to erupt for the following week.

\subsection{HOSPITAL EVACUATION}

The Phillips County Regional Medical Center was the one medical facility evacuated. Established in 1909, the Center moved to its present location across the highway from the fields surrounding the industrial park in 1979. It is a complete service hospital, providing care for residents in a 50-mile radius. The hospital currently employs 325-330 people and has 155 beds. Included in its services is obstetrical care; last year the center had 500 births. The not-for-profit, fully accredited facility is owned by the county but professionally managed by Quorum.

As part of the background investigation for this study, the hospital managers in charge of the evacuation were interviewed. The evacuation of the medical center was facilitated by efforts taken 6 months earlier to update the hospital's evacuation plan and reconfirm support agreements for relocation sites and supplies. At that time of updating the plan, the entire staff had also participated in a mock drill. When the safety officer observed the buildings across the highway being evacuated and started questioning officials on the possibility of also being evacuated, evacuation plans familiar to staff were in place and had been practiced. When the Director of Nursing gave the "Code White" alert (the signal that an evacuation to an off-site facility would follow) staff was amply prepared to move patients.

Interviews with staff indicated that all patients that could be discharged were sent home with a physician's nurse. Another four or five patients (the most seriously ill) were transferred to a hospital about a half hour away. The majority of the patients 
(approximately 17) in the rehabilitation unit were transferred to a vacant wing of the Crestpark Nursing home accompanied by hospital support staff. Only one maternity patient evacuated to the Phillips College Community College where the hospital staff had evacuated and opened emergency room services. The evacuation of patients began at 1:40 p.m. and all patients (except for two on ventilators and one being stabilized in the emergency room) were out 55 minutes later. The remaining three patients were evacuated 15 minutes later. A variety of vehicles transported patients-vans, schoolbuses, ambulances, private cars, and mortuary services. As a precaution, National Guard personnel provided security at the evacuated hospital.

The hospital would be reopened 6 days later. In the meantime, hospital personnel operated a triage area, an emergency room, and a laboratory at the recently completed fine arts building at the community college. The space provided by the college suited the hospital's needs. In addition to the space, there were dressing rooms with showers and toilets readily available. The college also has an Emergency Management Training (EMT) program and a school of nursing. One of the rooms used for training nurses was used to house maternity patients (there were two births) until stabilized, but no other patients were kept overnight. Ambulance operators rerouted patients to other medical facilities as needed. Staff maintained records using a notebook computer. The college also provide a separate extension line for hospital staff use.

Material Safety Data Sheets (MSDSs) were kept in the emergency room in case of a hazardous substance exposure to patients; however, the hospital staff found the information on recommended treatments to azinphos-methyl exposure difficult to retrieve because the MSDS information sheets are organized functionally, (i.e., fungicides, pesticides, herbicides) and not alphabetically. Thus, knowing the names of the chemicals involved did not help to immediately identify the appropriate treatment procedure even if patients reported exposure. The staff reported only three probable cases of exposure: two firefighters and one hospital employee who had been working below an intake vent at the facility at the time of the event.

The staff interviewed was highly critical of media coverage, considering it poor and unprofessional. Staff reported several people reporting to the temporary emergency room and requesting the "antidote" they had heard about from media sources. Those reporting to the emergency room with respiratory symptoms did not fit the exposure scenario. Hospital staff were also critical of the full-page advertisement taken out by a law firm in Little Rock that advised people with certain symptoms and at home at the time of the explosion to contact the firm. The staff also reported the confusion on location of emergency services provided by the hospital. Media reports indicated the hospital was still operating at its original location, even when the reporter was standing in a vacant parking lot secured by National Guard personnel. Staff made repeated attempts to correct false information when they heard a report but without success.

Although monitors indicated no contamination in the facility, the state health department required a thorough clean-up of the hospital before patients could be admitted. This meant that all horizontal hard services had to be scrubbed and all soft materials (drapes, etc.) had to removed. The health department also required that all filters in the building be replaced before the interior clean-up was started. Staff was unable to locate replacement filters because of the special design and the fact the company making them did not operate on weekends. Recognizing the urgency of having 
the regional hospital operational, pressure was exerted from state officials to convince the company to alter its policy. The company extended its hours and worked through the night, delivering the replacement filters to the hospital on Saturday. The hospital staff started cleaning on Sunday in shifts, starting with the rooms where filters were replaced. The emergency room was considered priority and cleaned first. On Tuesday ( 6 days after the initial evacuation) the hospital was reopened. The one incident neither hospital nor emergency officials could explain was the presence of 15 dead birds on the hospital grounds.

Communications were a problem when telephone lines jammed. Ham operators helped dispense information. The telephone extension line provided at the college also helped staff respond to medical emergencies. Changes in the hospital evacuation plans now include an "away team" to facilitate setting up operations at the evacuation site and more coordination with the off-site facility managers as well as managers of the chemical companies and with hazardous materials response agencies. The hospital now plans to include personnel from the community college in the mock drills to ensure better coordination in future events.

At the time of the accident, it was apparently not known that the Helena Fire Department could provide information on the hazardous materials as well as on chemical exposure because of their training. This link in communicating information is in the process of being corrected. In addition, the Phillips County OES has developed an information brochure titled "Helena/West Helena Emergency Information Citizen Guide" that lists local emergency numbers and national numbers that distribute information on chemicals. The guide also describes what citizens need to know if told to evacuate or to shelter.

\section{DATA COLLECTION AND METHODOLOGY}

This section describes the reasoning behind and the methods used to examine residents' behavior during the event. The similarity of the pesticide to Sarin, an organophosphate nerve agent, and the reports of atropine being flown in to treat victims suggested that this event could be used to examine how people responded to the situation that could easily have been a terrorist attack or accident involving a chemical warfare agent release. Prior to this accident, there had been no reported incidents in the U.S. that involved official advisories both to evacuate and to shelter-in-place for a hazardous chemical release. Thus the study was designed to focus on whether people heard the advisories, what they did, where they went, and if they did what they were told to do.

\subsection{SURVEY DATA}

Of the 154 surveys that were returned with usable data, 25 answered the screening question negatively and four were not usable, leaving 125 surveys for complete analysis. The screening question asked if the respondent was in the area told to evacuate or told to shelter. If the answer was no, the respondent was asked to return the questionnaire in the pre-paid envelope to us. Respondents still could request a copy of the 
report by filling out a form at the end of the survey. These request forms were taken from the survey without identification between the respondent's survey and the request. Anonymity was not considered an issue in this survey because the questions did not elicit any personal data outside of the broad demographics on age, background, and occupation. Many of those questions were not answered and thus the resulting distribution is not considered reliable.

\subsection{CONTRIBUTING DATA}

General demographic variables for Phillips County (where the chemical plant was located) were obtained from a number of sources, including the U.S. Census, the U.S. Dept. of Agriculture, and the State of Arkansas. Census data used in our analysis come from the STF1-A and PL94-171 files available on CD-ROM from the U.S. Dept. of Commerce. The STF1-A contains basic demographic data including population, households, age groups, race/ethnicity, and housing characteristics. The PL94-171 contains population as well as race and ethnicity data. These characteristics were used to provide a background for the study's findings as well as to help design of the survey. For example, the Census data indicated the number of Hispanics is very low (less than $1 \%$ ) in Phillips County compared to the number of Blacks (54\%) in the county, which is very high. This indicated that although the area affected by the release is in a prime agricultural area the questions did not have to include a Spanish translation.

Determining who was in the area at risk was facilitated when the Phillips County emergency management agency suggested we use the computerized 911 data base that contained information on addresses within areas told to evacuate or to shelter by officials. Consequently, the areas officially declared in the emergency zone could be examined in reference to what the residents thought they heard as warnings and eventually with what actions were taken. This was eventually translated into a data set that associated those who complied with official orders (compliers) and those who did not comply with official orders (non-compliers).

A survey was developed using questions drawn from other evacuation studies of hazardous events. Among those used were the questions similar to those from the Pittsburgh and Confluence studies conducted by Oak Ridge National Laboratory (ORNL) and the University of Pittsburgh. The questionnaire along with a cover letter and return envelope was sent to each residence, addressed to the head of household. The letter included the name and telephone number of the head of the Phillips County Emergency Service and contacts at ORNL in the event respondents had questions about the legitimacy of the survey. No questions were received at the ORNL although the OES coordinator reported some calls.

After 2 weeks, a follow-up postcard was sent reminding residents to return the questionnaire. After a month, a complete new package with a cover letter emphasizing the need for as many responses as possible was sent to all non-respondents. A local radio station volunteered to broadcast public service announcements asking people to return the questionnaires. We made no attempt to ensure confidentiality for respondents. Instead, we noted that no names would be associated with answers but that the results would be available to all who would be interested in the findings. With a $63 \%$ return, only one 
respondent enclosed a letter from an attorney stating the respondent had retained legal counsel. The questionnaire is reprinted in Appendix A.

When the surveys were returned, each was given an identification number, coded, and the data then transcribed to computer files. This eliminated personal names from association with the analysis but permitted geographic data to be retained. Systat ${ }^{\top M}$, a commercial statistical software package, was used to examine the distribution of variables and analyze the data when appropriate. After the data were entered and an initial analysis was completed, a letter report was sent to each of the respondents who submitted a request at the end of the survey. The letter report was reviewed by the Philips County OES and other officials before being sent to residents. The letter report is reprinted in Appendix C.

\section{FINDINGS}

Because the survey targeted two separate populations-those that were told to evacuate and those that were told to shelter-in-place-not all respondents answered all questions. For consistency, parallel questions for those that evacuated and those that sheltered-in-place were developed. Thus the responses and variables, such as length of time residents remained away or sheltered-in-place, can be compared. Of the total sample from which sufficient data were available, 117 residents $(78 \%)$ were in areas told to evacuate and $33(22 \%)$ were in areas told to shelter-in-place. Of the total responses from which survey data (125) were completed, $85 \%$ evacuated, $10 \%$ sheltered in place, and $5 \%$ did not take a protective action. When we look at behaviors in comparison to protective action areas, $90 \%$ of the respondents who were in the area told to evacuate by officials actually evacuated. Of those in the area told to shelter-in-place by officials, only $27 \%$ complied with the shelter-in- place order. Overall $76 \%$ complied with protective action orders and $24 \%$ did not.

One of the problems in not having direct contact with the respondent is the possible miscommunication about survey terms. We found that several respondents reported they had sheltered-in-place because they sheltered at a residence of a family member after they had evacuated their residence. However, because we did not ask the specific address of destination we were unable to determine if these respondents had actually sheltered-in-place in areas officially told to shelter. For purposes of the survey, all those who initially evacuated or were forced to evacuate (e.g., they could not return to their home because of road barriers) were called evacuees. All evacuees eventually returned to their residence. Those that purposely stayed at their residences throughout the event were considered to have sheltered-in-place. Those that sheltered did not have to take any special precautions, such as closing windows and doors, to qualify as "shelteredin-place."

Information was also obtained on how long it took respondents to reach their destination, how they learned the destination site was available, and where they went. Most respondents went to a friend's or relative's house or motel but several reported going to a casino across the Mississippi River, lending new meaning to the term "evacuation destination." 


\subsection{RESIDENTIAL CHARACTERISTICS AND KNOWLEDGE OF POTENTIAL THREAT}

Media reports, site reports, and information from the Phillips County Office of Emergency Services (OES) confirm that a 2-mile area downwind of the plant was initially evacuated and that those in the 2- to 3-mile area downwind were told to shelter. The data from the mail survey indicate that just under $54 \%$ of the respondents lived within 1 mile of the plant, another $20 \%$ lived within areas 1 to 2 miles of the plant, while the remaining respondents lived more than 3 miles from the plant. Table 1 shows the distribution of residences from the accident site as estimated by respondents.

These findings should be interpreted with caution because the survey question asked respondents how far their residence was from the chemical plant. Because no method for estimating the distance was given to direct respondents (such as asking for direct line of sight estimates), it is unclear if the distance was estimated by how far it was to travel by street or "as the crow flies." However, this part of Arkansas is very flat and it is likely that most respondents could observe the water tower located in the midst of the industrial park from their residence. One respondent estimated that their residence was 7 miles from the plant-an area well away from the areas told to evacuate or shelter.

Table 1. Distance in miles of residence from repackaging facility

\begin{tabular}{ccc}
\hline $\begin{array}{c}\text { Distance from plant } \\
\text { (miles) }\end{array}$ & Number of respondents & Cumulative percent \\
\hline 0 to 0.25 & 8 & 6.4 \\
0.26 to 0.50 & 22 & 25.0 \\
0.51 to 1 & 37 & 53.6 \\
1.1 to 2 & 25 & 73.6 \\
2.1 to 3 & 12 & 83.2 \\
$3+$ & 14 & 94.4 \\
Missing, unknown & 7 & 100 \\
\hline
\end{tabular}

Close to $6 \%$ of the respondents could or would not estimate the distance to the plant, many leaving question marks on the survey. Since we did not follow up with telephone inquiries to address such answers, we have no way of knowing where the residence was located. However, we visually surveyed the areas by vehicle at a later date and did not find any problems at that time. A map depicting those areas evacuated and those that sheltered is provided in Fig. 2.

Over $85 \%$ of the respondents reported living in a single-family residence. Another $10 \%$ lived in a mobile or manufactured residence and one reported living in a multi-family unit. Eighty-eight percent of the respondents reported owning the residence and just under $9 \%$ reported renting the unit. Table 2 shows the distribution of residential types as reported by respondents. 


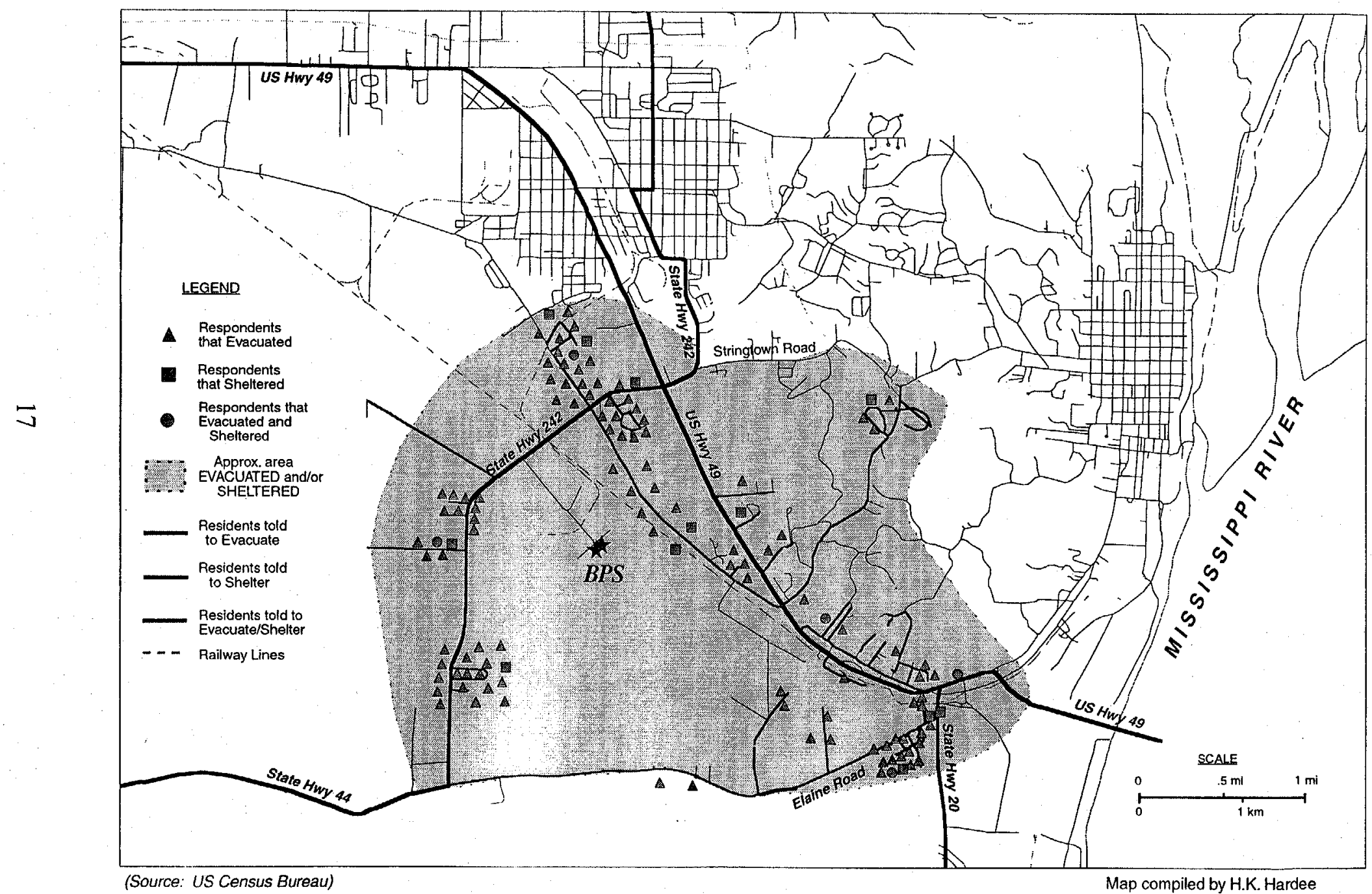

Fig. 2. Map depicting areas evacuated and those that sheltered. 
Table 2. Type of residence as reported by respondent

\begin{tabular}{lcc}
\hline \multicolumn{1}{c}{ Type of residence } & Number of respondents & Percent \\
\hline Single family & 107 & 85.6 \\
Mobile /manufactured unit & 13 & 10.4 \\
Condominium/apartment & 1 & 0.8 \\
Missing & 4 & 3.2 \\
\hline
\end{tabular}

Knowledge of the potential threat before the accident occurred was also examined. The survey question was structured into five parts: felt no threat at all, felt a slight threat, felt moderate danger, thought some accident was likely, and felt very severe danger from the plant. The responses were almost equally divided as to perception of threat. Twenty percent felt a moderate threat, while $38 \%$ thought there was some or very severe danger and $35 \%$ thought there was a very little (slight) or no threat from the plant.

Almost one-third (30\%) of the respondents reported they knew chemicals were stored at the plant, leaving about $64 \%$ who reported not knowing that chemicals were stored on site. The question did not ask if the respondent knew that some of the chemicals stored at the plant site were hazardous. There was no significant difference in distance from the plant for those that knew about the chemicals (mean $=1.69$ miles) versus those who did not know chemicals were stored there (mean $=1.61$ miles). The industrial site contains other chemical industries, including a chemical producing plant adjacent to (and highly visible from) the highway leading to the repackaging plant where the accident occurred.

\subsection{WARNING}

\subsubsection{Warning Source}

Oftentimes warnings are received unofficially by people in the area of risk before official warnings are issued. Contacts in Helena had told us that the first warnings were broadcast by a local radio station (KFFA) and deputies going door to door telling people to leave. Other researchers have demonstrated that neighbors, friends, and other family members often warn people informally before people receive a warning from authorities. This was borne out by this study's respondents. Forty-six percent of the respondents reported that they received their first warning from someone they knew-a family member, relative, neighbor, friend, or coworker. Thirty-six percent of respondents reported that official sources (police, fire personnel, emergency service personnel, or the sheriff) were the first to issue warnings to them. Some respondents reported learning of the accident through a police scanner at their residence. Only one person reported receiving the first warning from media. For a variety of reasons, some respondents never heard any warnings and learned of the accident when they tried to return home but were not allowed into their neighborhood until after the evacuation was over. Table 3 describes the first warning source. 
Table 3. Source of first warning as reported by respondents

\begin{tabular}{lcc}
\hline \multicolumn{1}{c}{ Source of first warning } & Number of respondents & Percent of total \\
\hline Police, fire, emergency services, sheriff & 45 & 36.0 \\
Media - TV or radio & 6 & 4.8 \\
National guard, state gov. & 1 & 0.8 \\
Neighbor, friend, co-worker & 32 & 25.6 \\
Family member/relative & 26 & 20.8 \\
Other/more than one source named & 12 & 9.6 \\
Missing & 9 & 2.4 \\
\hline
\end{tabular}

However, as with other studies of accidents, over one-half of those warned about the accident said the media were their best sources of information during the event, with $36 \%$ of those people saying television provided the best source of information. Another $26 \%$ said that talking with others, such as friends, neighbors, or relatives, was their best source of information. The findings are interesting because evidence from community sources indicates that the media did not always present accurate material nor would the media correct erroneous information, even when told a report was incorrect. Table 4 shows the distribution of responses on the reported best source of information during the event.

Table 4. Respondents' perception Best source of information during event

\begin{tabular}{lcc}
\hline Best source of information & Number of respondents & Percent of total respondents \\
\hline Television & 45 & 36.0 \\
Radio & 18 & 14.4 \\
Talking with others & 32 & 25.6 \\
Local officials & 10 & 8.0 \\
Other or more than one & & \\
source & 13 & 10.4 \\
Missing & 7 & 5.6 \\
\hline
\end{tabular}

\subsubsection{Time of Receipt of Warning}

Respondents were asked to indicate the time at which they received the first warnings. Those data are summarized in Fig. 2 as the cumulative proportion of the population warned by time respondents recalled being warned. Some people reported receiving some sort of warning before the explosion occurred. We suspect this is because the initial evacuation of employees from the building happened well before emergency responders were called to the scene and some employees may have called friends or relatives about the incident. Several respondents commented that the fire was well under way before the first official warnings were issued by authorities and that respondents left their residence before being warning because of the smoky haze, noise of explosion, and noxious fumes, (i.e., evidence of environmental cues). 


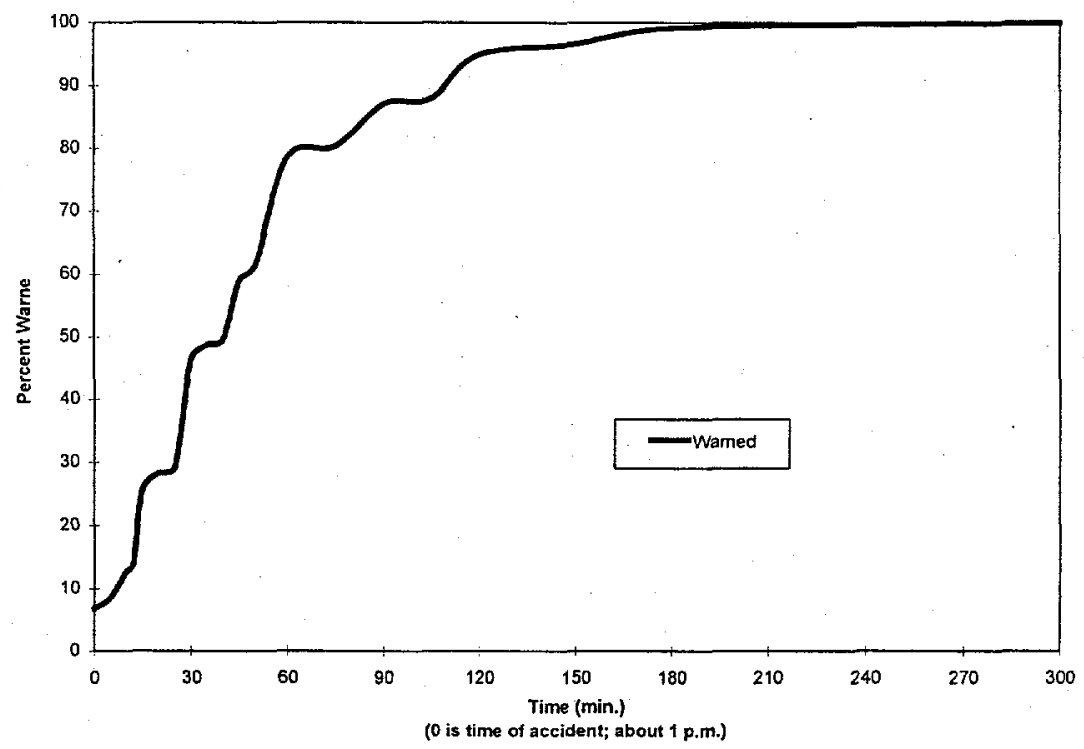

Fig. 3. When were people warned?

Also, officials went door-to door to issue warnings to those in the evacuation zones. Although such route notification takes more time to complete than other types of warning strategies, such as call-downs or voice notification sirens, people could have been warned unofficially by those already warned before authorities had finished their rounds. Almost $80 \%$ reported receiving their first warning within 1 hour. Figure 3 describes the time people left correlated with the time they heard the first warning.

Close to three-fourths (74\%) of those responding had been warned within 1 hour of the accident, which is consistent with findings from other studies on how quickly people are warned when officials have to rely on route alerting. Approximately twothirds of those that heard a warning totally believed the warning was true. Again, this may have been because of the presence of environmental cues-such as smoke and odors - that almost all respondents reported seeing or smelling.

Respondents were asked to estimate the time they evacuated after the accident occurred. Those data are summarized in Fig. 4 as the cumulative percentage of the respondent population evacuating by time after event. The time of evacuation is compared to the time respondents reported receiving their first warning. The difference between is the time for evacuation mobilization. The curve reflects a logistic pattern, with some people leaving quickly, followed by a bulge of people taking somewhat longer, and a few others lagging behind. 


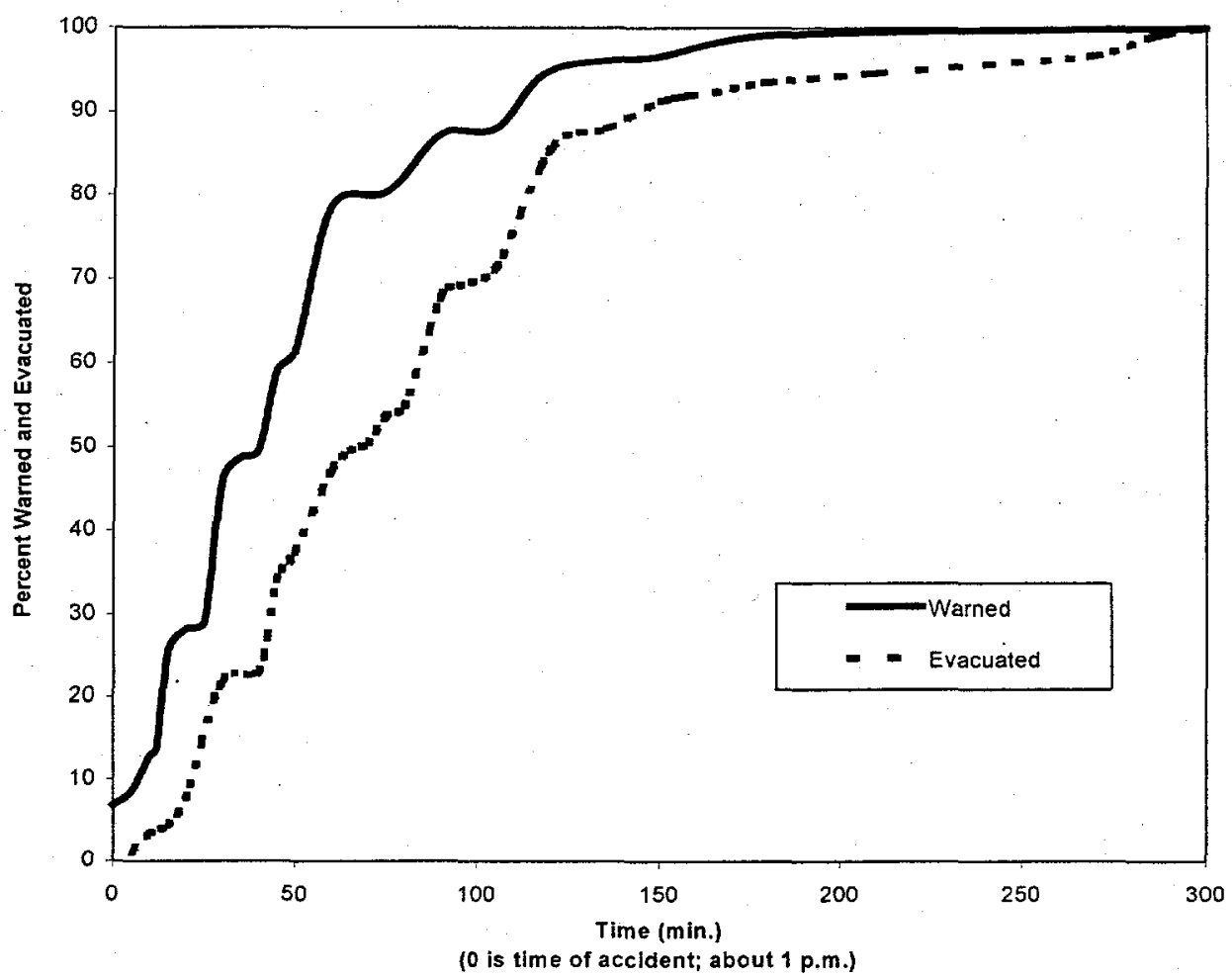

Fig. 4. When respondents evacuated compared to when respondents reported receiving first warning 9in minutes).

\subsubsection{Threat Perception}

People clearly recognized why they were being asked to evacuate or shelter (Table 5). Forty-two percent thought that the chemical cloud would reach their area within $10 \mathrm{~min}$. About one-third (30\%) of the respondents knew before the accident that chemicals were stored at the plant. However, people were evenly divided about the threat from the stored chemicals: $16 \%$ thought there was severe danger at the plant before the accident, $21 \%$ thought some accident was likely, $20 \%$ thought there was moderate danger, $17 \%$ thought there was a slight threat, and $18 \%$ thought there was no threat.

Table 5. Reported perception of threat from stored chemicals before accident.

\begin{tabular}{lcc}
\multicolumn{1}{c}{ Threat perception } & Number of respondents & Percent of total \\
\hline No threat at all & 22 & 17.6 \\
Slight threat & 43 & 16.8 \\
Moderate danger & 25 & 20.0 \\
Some accident likely & 27 & 21.6 \\
Very severe danger & 20 & 16.0 \\
Missing & 10 & 8.0 \\
\hline
\end{tabular}


The lack of concern about the threat from the chemicals prior to the accident may be attributed to habituation and/or geographical proximity to the industrial park. Over two-thirds $(66 \%)$ of the respondents had lived in their residences for more than 10 years. Less than $10 \%$ of the respondents reported living in their residences for less than 2 years. Several respondents pointed out that there were several other chemical plants in the area and that anyone living in the area would be aware of the chemicals at the facilities in the industrial park. Reports from the OES indicate that people in the area have occasionally complained about foul-smelling odors coming from the industrial park and asked if they were harmful. There was no correlation between perception of threat and distance from the plant $(\mathrm{r}=0.05)$.

\section{2.4 Warning Belief and Content}

Respondents were asked if they believed the warning when they first received it (Table 6). Only 11 reported they totally disbelieved the warning, with another 8 somewhat believing the warning. Seventeen moderately believed or mostly believed the warning, but the overwhelming majority-83 respondents (almost $67 \%$ )-totally believed the warning.

Table 6. Respondents' reported belief in warning

\begin{tabular}{lcc}
\hline Belief in warning & Count & Percent of total \\
\hline Totally believed warning & 83 & 66.4 \\
Mostly believed warning & 6 & 4.8 \\
Moderately believed warning & 11 & 8.8 \\
Somewhat believed warning & 8 & 8.8 \\
Totally disbelieved warning & 11 & 8.8 \\
Missing & 1 & 0.8 \\
\hline
\end{tabular}

Respondents were also asked about the content of the warnings. Six respondents recalled the warning contained precise protective action instructions. Seventy-eight respondents remembered being told to shelter or evacuate but not receiving any specific instructions. Finally, 27 indicated that they remembered a vague or nonspecific protective action recommendation.

\section{3 COMPANION ANIMALS}

Research, especially on hurricane evacuations, has suggested that people are more likely to evacuate with companion animals than leave them at the residence. This was not the case with those that reported evacuating in this study (Table 7). Sixty-five percent (82) of the respondents reported having pets. Of those that evacuated, 20 reported taking pets with household members, 18 left them inside the residence, 37 left them outside in 
yard, and 7 did something else. No one reported leaving animals in a car or taking them to a kennel while they evacuated. Some respondents reported they would not have left their animals outside if they had been able to return to their residence. One person reported finding their dog dead after returning home. Those that sheltered generally did not bring their pets into the residence to shelter with them, preferring to leave the animals in an outside structure or in the yard.

Table 7. Reported care of evacuee's companion animals

\begin{tabular}{lcc}
\hline Action taken with companion animals & Number of responses & Percent of total \\
\hline Took them with household & 20 & 24.4 \\
Left them inside residence & 18 & 22.0 \\
Left them outside residence & 37 & 45.1 \\
Other & 7 & 8.5 \\
Took to kennel/left in car & 0 & 0.0 \\
\hline
\end{tabular}

\section{4 EVACUATION BEHAVIOR}

Respondents were asked where they stayed during the evacuation. Most evacuees went to a home of a friend or relative when they evacuated (Table 8). Twelve went to a hotel (including a casino) or motel, while use of public shelters was extremely limited-only one person reported a public shelter as their destination. Nine people traveled to other places (such as a cabin they owned or on a planned trip). Twenty-one did not report a destination or the question was not relevant to their actions.

Table 8. Destination sites as reported by evacuees

\begin{tabular}{lcc}
\hline \multicolumn{1}{c}{ Destination of evacuee } & Number of responses & Percent of total \\
\hline Relative's residence & 64 & 51.2 \\
Friend's residence & 18 & 14.4 \\
Public shelter & 1 & 0.8 \\
Hotel or motel & 12 & 9.6 \\
Other & 9 & 7.2 \\
Missing or not applicable & 21 & 16.8 \\
\hline
\end{tabular}

Table 9 describes how respondents knew the evacuation destination was available. No one reported that they had made plans prior to the accident that included a specific destination in case of an emergency. 
Table 9. Availability (respondents could indicate more than one)

\begin{tabular}{lcc}
\hline \multicolumn{1}{c}{ How respondents knew of } & Number of respondents & Percent of respondents \\
\hline We knew the people. & 61 & 48.8 \\
They called us. & 9 & $7.2 \%$ \\
We called them. & 21 & 16.8 \\
Heard of evacuation center in & 6 & 4.0 \\
warnings. & 1 & 0.8 \\
Where people took us. & & \\
\hline
\end{tabular}

Over three-fourths of the people ( 81 respondents) reported they evacuated because the situation seemed dangerous. Another 23 did so to protect children, but no one left "to protect a pregnancy." A few people ( 9 respondents) feared a forced evacuation.

\subsection{SHELTERING-IN-PLACE BEHAVIOR}

The information on those that sheltered-in-place may not be representative of those that sheltered because only 11 people reported sheltering. Those who reported sheltering remembered being told to shelter-in-place and being given some instructions. Three who sheltered remembered very specific instructions on sheltering.

Most people (9) sheltered because the situation seemed dangerous or because authorities told them to stay indoors (6). No one sheltered to protect a pregnancy. Others had no place to go so stayed inside, two sheltered to protect children, and two others reported being pressured by someone outside the immediate family to stay indoors and shelter.

People were asked what actions they took when sheltering. People could select as many actions as they wanted and actions were not prioritized. Expedient actions of sheltering respondents included closing doors (17 people), closing windows (15), and turning off heating and cooling systems (12). Only two others taped windows and doors or put towels across doorways. Most people (11) reported sheltering overnight (10 to $12 \mathrm{~h}$ ) in their residence.

How people learn to stop sheltering or the appropriate actions to take after an event is officially over has not been well studied. In this event we used 10:00 p.m. as the "official" end because officials allowed evacuees to return to their homes at 10:00 that evening. Respondents were asked who told them it was safe to stop sheltering and what they did when they finished sheltering. Twelve people reported that they gained such information from television or by listening to the radio. Ten people learned it was safe to stop sheltering from the local police department. No one reported having a family member or coworker tell them it was safe, but four recalled having a neighbor tell them it was safe to stop sheltering.

A question listed a number of actions, including a write-in category to elicit data on actions taken by respondents after they finished sheltering. Multiple responses were possible. Actions that people took after sheltering included 
- venting the residence (5 reported opening doors and windows),

- taking care of animals (5),

- calling relatives and friends (7)

- listening to the media $(10)$,

- washing household items (4), and

- showering or bathing (9).

Eight respondents reported doing "nothing special" after sheltering.

\subsection{PERCEPTIONS OF DANGER DURING EVENT}

Less than $33 \%$ of the all respondents felt very or somewhat safe during the event. Most respondents reported (41\%) feeling very unsafe with $24 \%$ feeling somewhat unsafe. Approximately $36 \%$ of respondents answering the question on whether their daily activities had been changed since the incident reported feeling their normal daily activities had changed since the event. Over $56 \%$ of those responding to the question reported no change all. For those that felt their daily activities had been changed, only 12 reported the change had been substantial while 20 reported the change as moderate or minimal.

\subsection{DEMOGRAPHICS}

One-half of the respondents who provided an answer to the survey question on age were under 54 years of age. No respondents reported their age as under 24. Just under $25 \%$ of the respondents to the question were between the ages of 55 to 64 and the rest (22\%) were over 65 . This was expected as the accident occurred just after one o'clock in the afternoon while most people with jobs were working and children were at school. We had also asked for head of household to fill out the survey.

Fifty-six percent of the respondents who answered the question on race and ethnicity indicated they were Caucasian and $21 \%$ were Black. Only one person reported being Hispanic. Twenty-two percent would not reveal their racial/ethnic background. The lack of complete data limits our ability to determine the racial or ethnic characteristics of the survey respondents and for comparisons to county and city data. The finding is also not consistent with the percentage of Blacks as reported in the 1990 Census count for the general population within Phillips County.

The findings on income levels are also problematic for similar reasons. One-half of the respondents had incomes lower than $\$ 20,000$ per year, with $29 \%$ under $\$ 10,000$, indicating a number of respondents living below poverty. Almost $10 \%$ of those that responded to the question had annual family incomes greater than $\$ 50,000$. 


\section{SUMMARY AND CONCLUSIONS}

Evacuation is commonly used by emergency officials faced with hazardous chemical releases. In fast moving events, asking people to evacuate may not be advisable if residents must travel through a plume before reaching a safe destination or if the plume's direction is constantly shifting. Conversely, officials should be reasonably sure that residences or other structures will provide necessary protection when advising people to shelter-in-place. The degree of protection offered by a building depends on how leaky the structure is, which is measured by the air infiltration rate. Similarly, how long a chemical substance will remain in a structure will depend on how "tight" the building is and how quickly the inside air is replaced with outside air.

The rate of air infiltration became an issue in the late 1960s. Houses constructed before 1965 were not required by building codes to include energy conservation standards. When energy conservation became a national issue, air infiltration into residences decreased as new construction incorporated energy conservation measures required by the stricter building codes. The energy standards that were developed meant that newly constructed housing consumed much less energy - and consequently had far less outside air infiltration - than houses built before 1965. However, in mild or moderate climates, energy conservation or weatherization techniques are less likely to be used because of the added cost without the benefit.

It is unknown how many of the residences surrounding the industrial park where the accident occurred were constructed before 1970 or had been retrofitted with weatherization measures. The number of mobile or prefabricated structures is also problematic because of their lightweight construction and increased leakage from exposed flooring. The authors of this report observed the general condition of the residential areas affected by the release and concluded that many of the structures would offer inadequate protection for sustained releases. Photographs are reproduced in Appendix A.

Often environmental cues from the release contribute to people's awareness and propensity to leave the area at risk. Research is not definitive on what alerts people to shelter-in-place. The main premise behind tornado sirens is to alert people to go inside and listen to the emergency broadcast station. The findings from the West Helena study indicate that most people that responded to the survey saw or smelled evidence of the plume of toxic materials released from the fire. Thus people told to shelter-in-place likely saw or smelled the smoke. Although emergency personnel in Helena sounded the tornado sirens as an alert, no respondents reported being warned by the sirens. The alert signals used in Phillips County were intended to differentiate between tornadoes and other types of hazards. Since the incident, The Phillips County OES has developed a public information brochure that stresses the differences between the two alert signals as well as the actions people should take when they hear the sirens.

Several other external factors may help explain why most respondents in this study choose to evacuate rather than shelter-in-place and why the number of people evacuating (compliers) was so high (almost 90\%). We suggest that the poor physical condition of many of the residences in the area surrounding the industrial park may have contributed to the inclination of residents to evacuate their residences. This area of 
Arkansas has historically been farmed with cheap labor and many of the structures in the rural areas reflect the tradition. The area is also flat with many older residences elevated above their foundations to avoid flooding. Both the age and condition of residences would indicate that protection provided by a residence would be questionable in a toxic chemical release.

The second factor may reflect "contagion," wherein an observer of a friend's or neighbor's behavior chooses to follow that behavior rather than an "official" recommendation. For example, the regional medical center started to prepare for a possible evacuation when mangers saw businesses across the highway from the facility being told to evacuate. This prompted the managers to question officials about an evacuation, not the other way around.

Another factor may be the ready availability of sanctuary provided by family members and friends. As Drabek (1989) and others (Perry, Lindell, and Greene 1981) have noted, if kin are within a reasonable distance, evacuees generally prefer to go to the home of relatives. In this study, most people reported spending 10-15 $\mathrm{min}$ to get to the destination site, most frequently a relative's residence. The evacuation sites were close to the evacuee's homes but offered protection. How long the fire would burn and send the toxic cloud aloft was uncertain to officials and residents alike.

\subsection{ROUTE ALERT WARNING TIMES}

The route alert warning times from this survey coincide with similar findings from other studies of toxic chemical releases (Rogers, Shumpert, and Sorensen 1990). Three-fourths (74\%) of the respondents had been warned within 1 hour of the explosion. Such notification times are inadequate to protect residents if a short warning time was available, such as if the explosion had been a precursor to other explosions. As in other events, however, informal warnings through family, friends, relatives, and coworkers provided rapid notification $(46 \%)$.

\subsection{COMPLIANCE}

The main finding from this study has to do with compliance with official orders. The surveyed population was identified initially from the 911 database which had been given a variable indicating whether the address was in the evacuation zone or in the areas told to shelter. We were able to correlate what respondents reported doing with the officially documented areas of the two advisories.

Table 10 presents the findings on compliance. Although a much lower number of people were in the area told to shelter (22\%) than in the area told to evacuate $(78 \%), 27 \%$ of those told to shelter complied with the shelter-in-place order but approximately $90 \%$ evacuated who were in the area told to evacuate by officials. This means overall that $76 \%$ complied with protective action orders but $24 \%$ did not. The low level of compliance with the sheltering order suggests that residents may not be willing to shelter if the option (and means) to evacuate are available. 
Table 10. Compliance with warnings

\begin{tabular}{lcccc}
\hline & Evacuated & Sheltered & $\begin{array}{c}\text { Neither } \\
\text { evacuated } \\
\text { nor sheltered }\end{array}$ & $\begin{array}{c}\text { Total } \\
\text { number of } \\
\text { responses }\end{array}$ \\
\hline Evacuation areas & $90 \%$ & $5 \%$ & $5 \%$ & 97 \\
& $(87)$ & $(5)$ & $(5)$ & \\
Sheltered areas & $68 \%$ & $27 \%$ & $4 \%$ & 26 \\
& $(18)$ & $(7)$ & $(1)$ & \\
Percent of total & $85 \%$ & $10 \%$ & $5 \%$ & 123 \\
responses & $(103)$ & $(12)$ & $(6)$ & \\
\hline
\end{tabular}

Findings of those who sheltered in place should be viewed as problematic because of the paucity of data and should not be used to generalize to all those who sheltered in this study or to other studies in which people sheltered.

\subsection{ADDITIONAL ISSUES}

Several issues are raised in this study that require further research. One of the most critical is attaining a better sense of people's response to warnings, particularly in how people can be mobilized to respond to rapidly evolving hazardous events which require immediate response. Secondly, information is needed as to how to succeed in getting people to effectively shelter-in-place. It is clear both decision-makers and populations at risk must be knowledgeable about the circumstances and appropriate precautions that permit residents to safely shelter-in-place when advised to do so. This includes public education on effective shelter-in-place strategies (e.g., closing windows, vents, using towels or tape to prevent leaks, etc) as well as on timely implementation (e.g., actions must be completed before a plume arrives and the structure should be immediately vented following the all-clear signal). Decision-makers should also be knowledgeable about substandard housing characteristics or other conditions (e.g., a large number of mobile homes) that suggest sheltering advisories are not warranted for certain locations.

Another issue needing further investigation is the perception of risk because of geographical proximity of the residence or because of employment in a risky environment. Drabek's (1986) studies on natural hazards suggest that employment in occupations that have associated risks, such as logging or ocean fishing, may decrease overall sensitively to risks. Working with hazardous chemical substances, such as the relatively benign repackaging of agricultural chemicals, may have contributed to feelings that the event could be handled internally and consequently to the length of time it took to sound the warning and alert the community of a potential problem. 
A further issue is the training of volunteers in rural communities to respond to such events. Rural communities are often hampered by lack of resources to provide expensive personal protective equipment or training to volunteer responders. Volunteers also may lack time to enhance their response skills. Although more training may not have saved the lives of the firefighters, it is likely that more information on the hazards of chemicals stored might have prevented the firefighters from entering the structure without proper protective equipment.

Defining compliance with advisories is another issue. The findings from this study indicate that most people tried to follow what they thought they were told to do by authorities. Thus residents may consider themselves compliant with official advisories but authorities would not necessarily agree. If geographical locale is to used as a determinant for advising more than one protective action, public information must be consistent and given repeatedly over multiple channels to enhance people's chances of hearing the official warning for their particular location. In the chaos of fast-moving events, it is often difficult and sometimes impossible for emergency managers and officials to alter priorities to adjust for information dissemination.

The results from this study indicate that sirens were likely not an effective mechanism in getting people to seek more information. This is consistent with findings from other studies that many people have difficulty remembering the distinction between different siren signals. It appears that the environmental cues of smoke and odor alerted people to seek out the source of the problem. It is also unclear if the use of local broadcast media to reach the affected residents was a successful strategy since some interviews with informants indicated that erroneous information was being transmitted via some media. Thus a resident could receive very different messages (e.g., the hospital is available for emergencies versus the hospital has evacuated) by listening to multiple media outlets.

Finally, we suggest that the implications of shelter-in-place advisories may not be completely understood by emergency managers and responders. This is particularly an issue when residents are advised to shelter-in-place in structures that will not protect them. It is also an issue when the chemical release continues for an extended time period. If the release is prolonged, the air exchange rates of structures will result in cumulative exposures within the structure equal to those that would be received outside, offering no protection to residents. If structures are not adequately vented after the release is over, persons remaining in the structure can be further exposed to the chemically contaminated inside air. Thus a sheltering advisory should not be used as a routine precautionary measure but with well defined strategies and information that ensure maximum protection for residents.

Civilian authorities use evacuations as standard protective actions for various types of hazards and emergencies. Although some residents may refuse to evacuate for any reason, mandatory evacuations are familiar, generally easily enforced, and do not require residents to make individual decisions as to stay or leave-- everyone is expected to leave and go to a safe place. Sheltering-in-place, on the other hand, is not as well practiced and the resident can choose to stay or leave without officials' knowledge. Officials are not likely to enter areas told to shelter-in-place while the release is occurring to ensure residents are safe and may not be able to get the message to residents to vent structures in a timely manner. While some populations living close to clustered 
hazardous facilities (e.g., Institute, West Virginia) may be advised to shelter-in-place several times a year, it is not a common procedure for rural areas with scattered facilities. The West Helena event indicates that given dual warning advisories, the decision to evacuate or shelter in a hazardous chemical release will likely follow how the event is perceived by the individual and what that individual believes is the warning advisory.

\section{REFERENCES}

Alberta Public Safety Services. 1992. A Technical Study of Shelter Versus Evacuation When Faced with a Release of Hydrogen Sulfide. Edmonton, Alberta, Canada: Alberta Public Safety Services.

Allen Bartlo, Owner BPS, West Helena, AK, to John Sorensen, ORNL, 2/23/98.

Arnold, B., Safety Director, Helena Regional Medical Center, personal communication to B. Vogt, ORNL, 2/23/98.

Batts, V., Phillips County Office of Emergency Services, personal communication to B.Vogt, ORNL, 2/23/98.

Brown, M. A., Berry, L. G., Balzer, R. A. and E. Faby. 1993. National Impacts of Weatherization Assistance Program in Single-Family and Small Multifamily Dwellings. )ORNL/Con-326. Oak Ridge, TN: ORNL.

Chambers, J. Director of Marketing Helena Regional Medical Center, personal communication to Barbara Vogt, ORNL, 2/19/98.

Cunningham, M., Philips County Office of Emergency Services, personal communication to $\mathrm{H}$. Hardee, University of Tennessee, 5/22/97.

Drabek , T. E. 1983. "Shall we leave? A study on family reactions when disaster strikes," Emergency Management Review Vol. 1 (Fall) pp. 25-29.

Drabek, T. E. 1986. Human Responses to Disaster - An Inventory of Sociological Findings. New York, NY: Springer-Verlag Inc.

Drabek, T. E. 1996. Disaster Evacuation Behavior, Tourists and Transients, Monograph No. 58. Boulder, CO: Institute of Environment and Behavior, University of Colorado.

EPA (U.S. Environmental Protection Agency). 1986 (Sept.). Pesticide fact sheet for azinphos- methyl. Fact sheet no. 100. Office of Pesticide Programs. Washington, D.C. 
ERCB (Energy Resources Conservation Board) and Alberta Public Safety Services. 1992. A Technical Study of Shelter Versus Evacuation When Faced with a Release of Hydrogen Sulphide. Edmonton, Alberta, Canada: Alberta Public Safety Services.

FEMA (Federal Emergency Management Agency). 1995. On the Road to Protecting the Public - Unraveling the Mysteries. Policy document presented at the National Institute for Chemical Studies Conference, Sept. 20-21, 1995.

Michigan Dept. of State Police. 1994. Warning, Evacuation \& In-Place Protection Handbook. Developed by CARE Planning Services, P.C. with Michigan Dept. of State Police, Emergency Management Division.

New York State Department of Health. 1984 (June). Chemical fact sheet: Guthion. Bureau of Toxic Substances Management. Albany, NY.

Occupational Health Services (OHS), Inc. 1991 (Feb. 25). MSDS for Azinphos-methyl. OHS Inc., Secaucus, NJ.

Perry, R. W., Lindell, M. K., and M. R. Greene. 1981. Evacuation Planning in Emergency Management. Lexington, MA: Lexington Books.

Quarantelli, E. L. 1980. Evacuation Behavior and Problems: Findings and Implications from the Research Literature. Columbus, $\mathrm{OH}$ : Disaster Research Center, Ohio State University.

Rogers, G. O., Shumpert, B. L., and J. H. Sorensen. 1990. Description of Interview Data Regarding Pittsburgh and Confluence Toxic Chemical Accident.

ORNL/TM-11599. Oak Ridge, TN: ORNL.

Salmon, J. D. 1984. "Vertical evacuation in hurricanes: An urgent policy problem for coastal managers," Coastal Zone management Journal 12 (2/3): pg. 287-300.

Sorensen, J. H. 1992. "Warning and warning response," paper presented at the Assessment of Research and Applications on Natural Hazards, July 8-11, 1992. Fort Collins, $\mathrm{CO}$

Sorensen, J. H., Vogt, B. M., and D. Mileti. 1987. Evacuation: An Assessment of Planning and Research.. Oak Ridge, TN: Oak Ridge National Laboratory. (Reprinted by FEMA as Report 1212-9).

U.S. Dept. of Commerce. 1996. Land Area, Population, and Density for States and Counties: 1990, US Census Bureau Released: March 12, 1996, Washington, DC.

U.S. Dept. of Commerce, Bureau of the Census, 1992 Census of Agriculture Vol. 1 Part 4 Arkansas. 1992, Washington, DC. 
Vogt, B. M. 1990. Evacuation of Institutionalized and Specialized Populations.

ORNL/SUB-7685/1 \& T23. Oak Ridge, TN: Oak Ridge National Laboratory.

Vogt. B. M. 1991. Evacuation in Emergencies. Knoxville, TN: University of Tennessee, Knoxville, TN.

Vogt, B. M. and J. H. Sorensen. 1992. Evacuation Research: A Reassessment. ORNL/TM-11908. Oak Ridge, TN: Oak Ridge National Laboratory.

Vogt, B. M. and J. H. Sorensen. 1994. Risk Communication and the Chemical Stockpile Emergency Planning Program. ORNL-6824. Oak Ridge, TN: Oak Ridge National Laboratory. 


\section{APPENDIX A: VIEW OF PLANT AT TIME OF EXPLOSION AND REBUILT FACILITY; VIEW OF RESIDENCES CLOSE TO PLANT; VIEW OF REGIONAL MEDICAL CENTER}




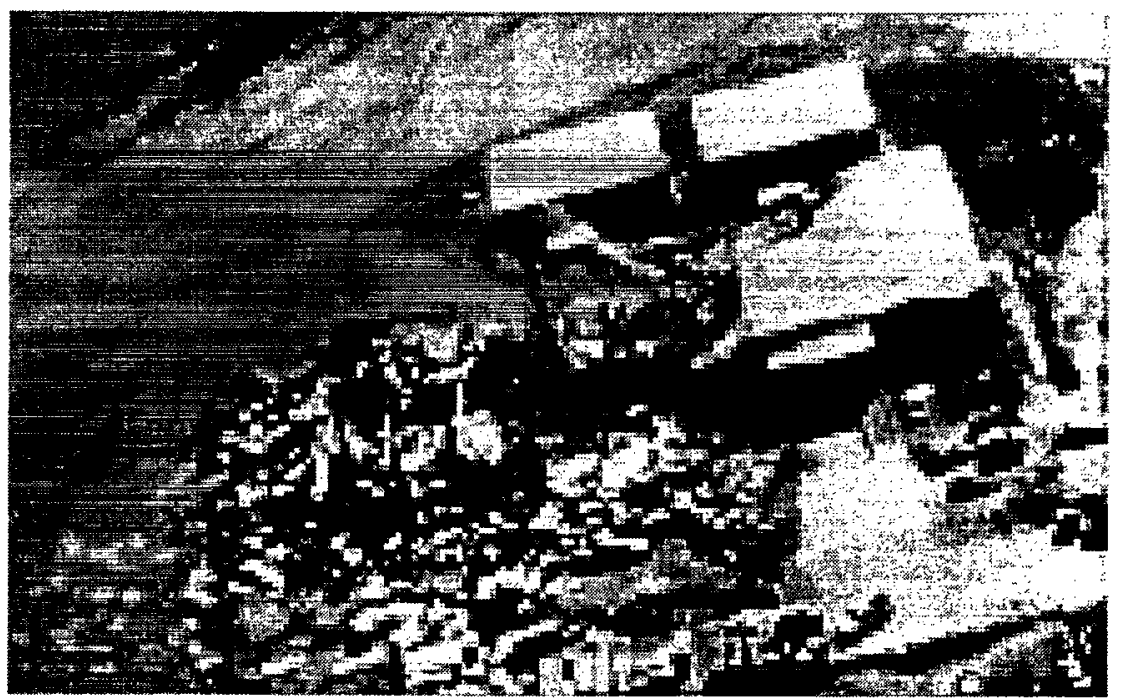

Fig. A.2.1. View of plant following explosion.

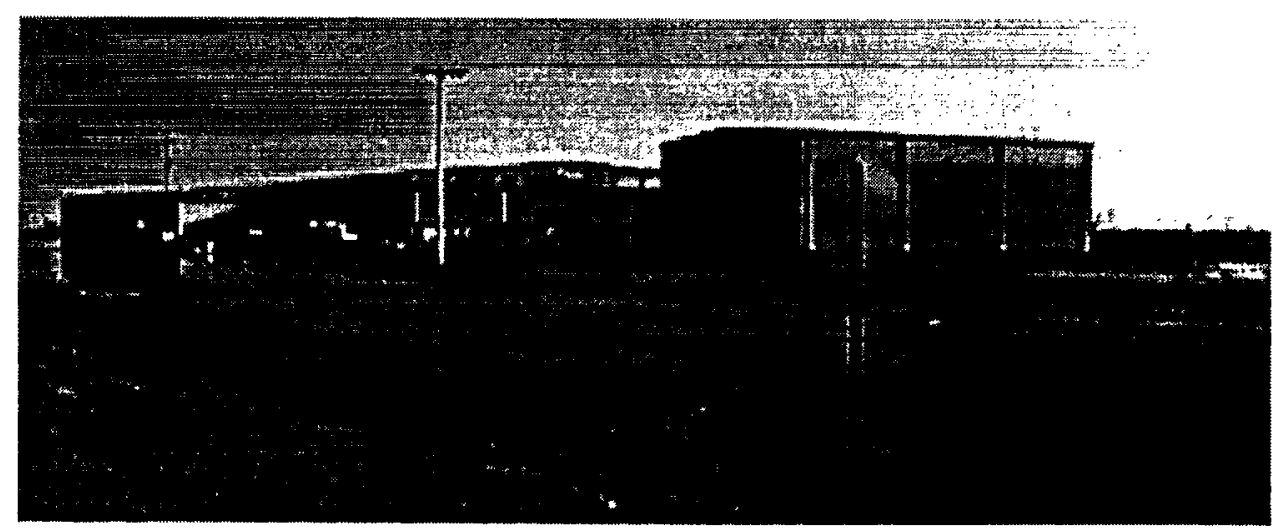

Fig. A.2.2. View of rebuilt plant. 

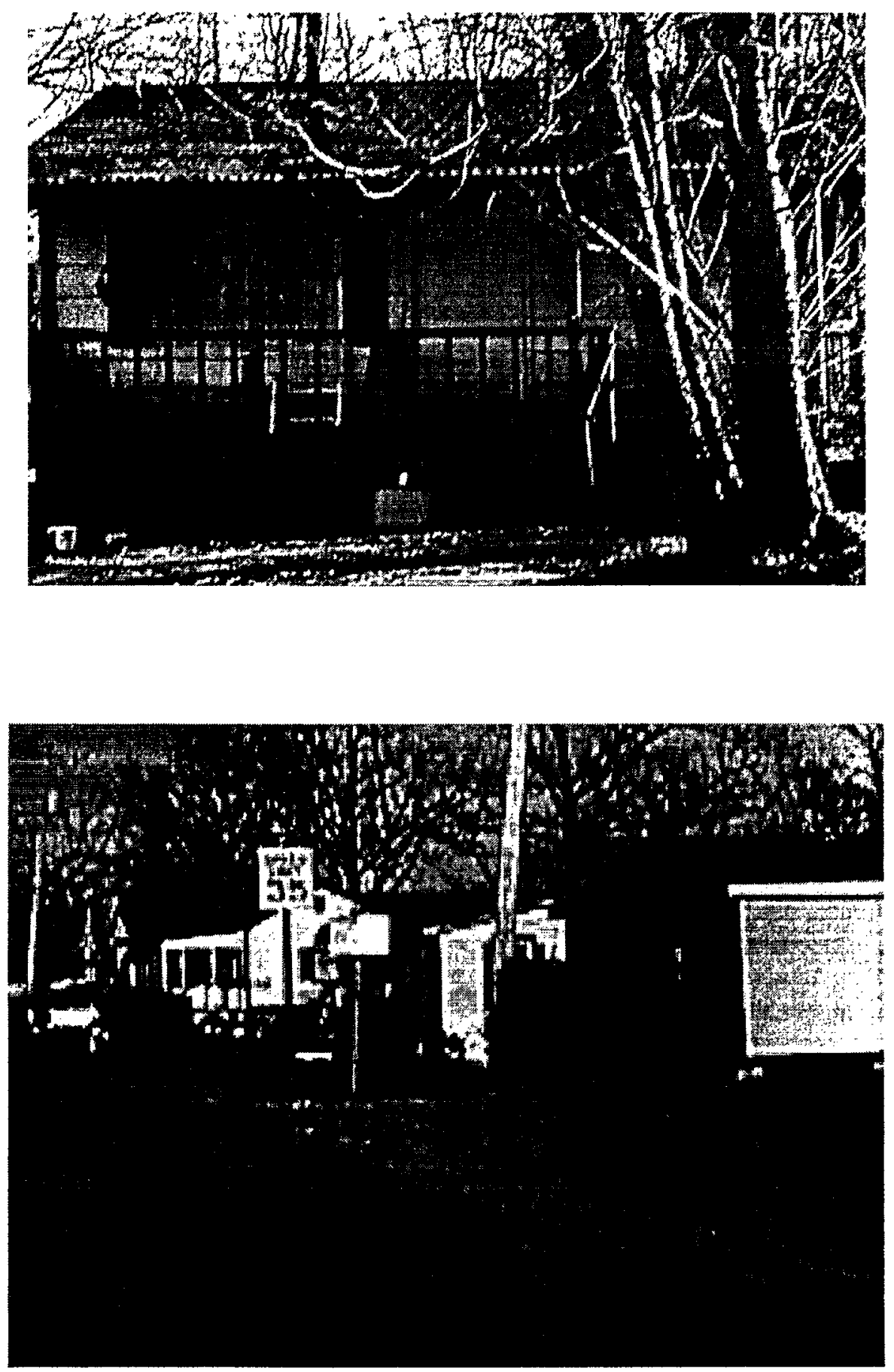

Fig. A.2.3. View of housing in area. 


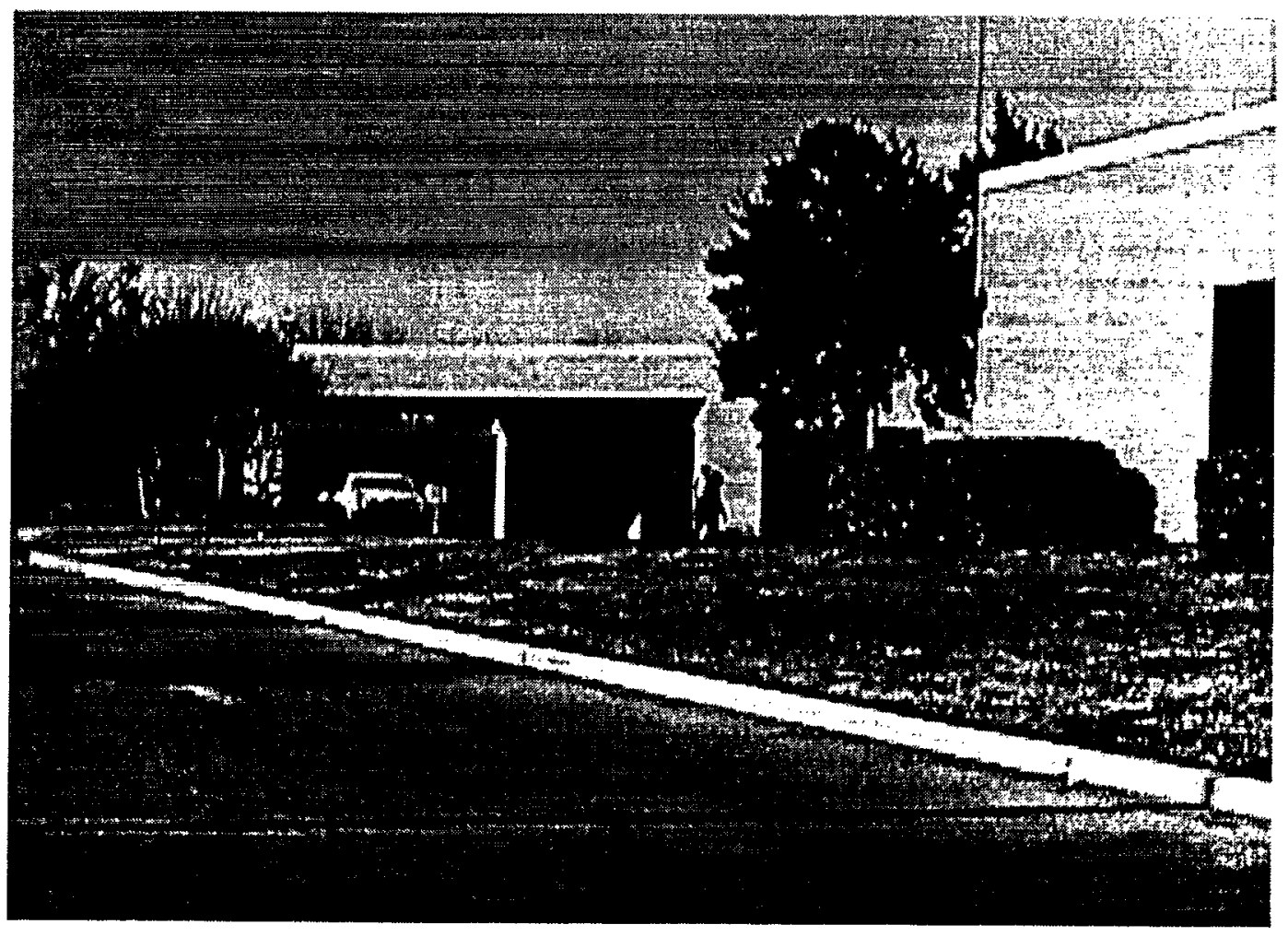

Fig. A.2.4. View of Regional Medical Center. 
APPENDIX B: COPY OF QUESTIONNAIRE AND INTRODUCTORY LETTER 
Dear Head of Household:

Thank you for taking the time to answer the questions in this survey. Most of the questions require you to circle the answer but others will ask you to provide information. Please answer as many questions as possible. There are no wrong answers. The information you provide will help emergency managers and scientists understand how people respond to chemical accidents when told to evacuate or shelter.

The questions are divided into sections. The first section asks about your residence and requests some background information on your household.

Q.1 Were you or any members of your household at home or in the area told to evacuate or shelter-in-place when the fire occurred at the chemical plant on May 8, 1997? (circle only one)

YES NO Other, please explain

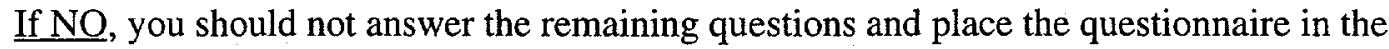
pre-paid envelope and mail it to us.

If YES, how long have you lived at this address? (circle only one)

$$
\begin{aligned}
& \text { less than one year } \\
& 1-2 \text { years } \\
& 2-4 \text { years } \\
& 5-10 \text { years } \\
& 10+\text { years }
\end{aligned}
$$

If YES, do you own or rent? (circle only one)

$$
\text { Own Rent Other, please explain }
$$

Q.2 Please describe your residence (circle only one)

single-family house

mobile home

condo or apartment building

other, please specify

Q.3 Approximately how far is your home from the chemical plant that had the fire? (please give a number)

miles from chemical plant 
Q.4 How many people were at home at the time of fire at the chemical plant ? (circle numbers)

$\begin{array}{llllllll}\text { male adults at home } & 0 & 1 & 2 & 3 & 4 & 5 & 6+ \\ \begin{array}{l}\text { female adults at home } \\ 0\end{array} & 1 & 2 & 3 & 4 & 5 & 6+ \\ \begin{array}{l}\text { children at home } \\ \text { under age 16 }\end{array} & 0 & 1 & 2 & 3 & 4 & 5 & 6+\end{array}$

Q.5 How many children under 16 live at home? (please give number)

total number of children under 16 at home

Q.6 Not including your own household, how many other family members and relatives live in Phillips County? (circle only one)
None
0 to 4
5 to 9
10 to 14
15 to 19
20 or more

Q.7 Do you have pets at your home? (circle only one)

YES NO

Q.8 Do you have livestock at your home? (circle only one)

YES NO

Q.9 Before the recent fire at the chemical plant, did you know that toxic chemicals were stored at the chemical plant? (circle only one)

YES NO Other, please explain

Q.10 Before the recent fire at the chemical plant how would you have described the possibility of a chemical release in your immediate area? (circle only one)

no threat at all

slight danger

moderate danger

some chemical accident was likely

very severe danger

Q.11 Before the recent fire at the chemical plant, had you ever evacuated or sheltered in your home because of a chemical release? (circle only one)

YES

NO

If YES, how many times have you evacuated because of a chemical release?

None Once 2 to 3 times 4 to 5 times More than 5 times

If YES, how many times have you sheltered because of a chemical release? 
None Once 2 to 3 times 4 to 5 times More than 5 times

The next section asks you how you learned of the accident and what you did after being warned a chemical had been released during the fire.

Q.12 At the time you heard the first warning, did you smell or see any evidence of a chemical release from a fire? (circle only one)

YES NO

If YES, please describe what you saw or smelled

Q.13 The fire started at approximately 1:00 p.m. At what time did you first hear a warning about the accident at the chemical plant?

time

Q.14 How did you receive the first warning message about the chemical release?

(circle only one)

telephone call

face-to-face from another person

watching television

an authority going door-to-door

listening to radio

street loudspeaker

permanently mounted siren

other, please specify

Q.15 What was the source of the first warning message? (circle only one)

Police

Fire department

Office of emergency services

Sheriff's department

Television

Radio national guard

state governor's office

neighbor or friend

co-worker

family member or other relative

other, please specify 
Q.16 How would you describe your feelings about the credibility of the source from which you first received a warning? (circle only one)

The source is highly reliable and trustworthy; they always act in a responsible manner.

The source is almost always reliable and trustworthy; they almost always act in a responsible manner.

The source is usually reliable and trustworthy; they usually act in a responsible manner. The source is sometimes not reliable and trustworthy; they periodically make important mistakes.

The source is often not reliable and trustworthy; they frequently make important mistakes. Can't remember

Q.17 On the following scale, how would you rate the extent to which you believed this first warning? (circle only one)

totally disbelieved somewhat disbelieved moderately believed mostly believed totally believed

Q.18 Were you at any time in the warnings told or asked to listen to any specific radio or TV station for additional information on the chemical release? (circle only one)

YES NO Don't know

If YES, who told you to listen to that radio or TV station?

local police state police

fire department sheriff's department television radio national guard neighbor or friend Phillips County Office of Emergency Services co-worker family member or other relative other, please specify

Q.19 What was your best source of information during the event? (circle only one)

television

radio

talking with neighbors, friends, relatives, other people

local authorities/officials

other, please specify 
Q.20 After hearing the first warning, how much time did you believe there would be before the chemical cloud reached you area? (circle only one)

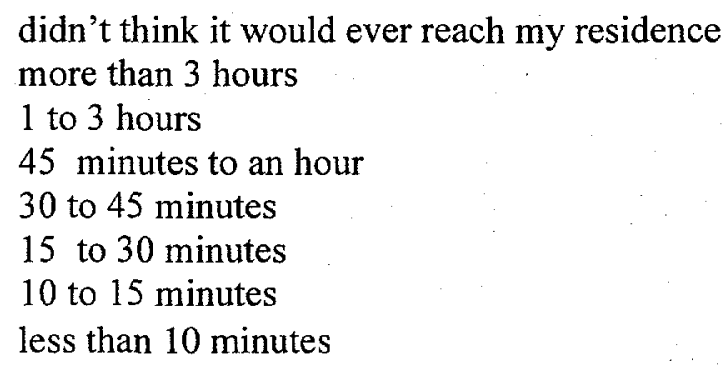

Q.21 We're interested in knowing everyone who told you about the chemical release. Here is a list of some possible sources from which you may have received information during the emergency. (circle all that apply)

city officials

county officials

state officials

fire department police department

people at school
American Red Cross

utility company

network TV

cable TV

radio (AM or FM)

local business friends

family/relatives

neighbors

service organizations or clubs other, please specify

Q.22 Were all members of your household at home at the time of the fire at the chemical plant?

YES

NO

If YES, what did you do about members of household that were not at home?

(circle only one)

tried to contact them to tell them to go to a safe place tried to contact them to tell them to meet you at a safe place waited at home for them to return home before leaving left for a pre-arranged safe meeting place where the absent people knew to go in the event of an emergency other, please explain

Q.23 During the recent fire at the chemical plant, were you told to evacuate? (circle only one)

YES NO

Q.24 During the recent fire at the chemical plant, were you told to shelter (stay in your home or building)? (circle only one)

YES NO 
Q.25 Did you evacuate or shelter in your residence during the recent chemical release? (circle only one)

Evacuated Sheltered Other, please explain

This section is for people who evacuated. If you did not evacuate, please skip Questions 26 through 36 and go directly to Question 38.

Q. 26 If you or your household evacuated, what statement below best describes what you were told about evacuating? (circle only one)

heard no warning to evacuate

heard a warning, but not told to evacuate

warned to evacuate, but not told where to go

warned to evacuate and given general instructions

warned to evacuate and given precise instructions

other (please specify)

Q.27 If you or your household evacuated -- Please circle the reasons below that caused your household members to evacuated? (circle all that apply)

Situation seemed dangerous

To protect children

To protect pregnancy

To avoid the confusion of a forced evacuation

Pressure from someone outside the family

Trip planned before accident

Don't know

Other, please specify

Q.28 If you or your household evacuated, when did you actually leave your home?(give approximate time)

time

Q.29 If you or your household evacuated, where did you go? (circle only one)

to a relative's home

to a friend's home

to a public shelter

to a hotel or motel

other, please specify 
Q.30 If you or your household evacuated, what did you do with your animals?

(circle all that apply)

took them with household members

left them inside home

left them outside in yard

left them in car

took to a kennel

other, please specify

Q.31 If you or your household evacuated, how did you know the place you evacuated to was available? (circle all that apply)

we knew the people

they called (or contacted) us

we called (or contacted) them

heard about evacuation center in the warnings

that's where the people who evacuated us took us

knew it was a safe place because we previously planned to go there if a chemical accident ever occurred

other, please explain

Q.32 If you or your household evacuated, how much time did it take to travel to your destination?

time

Q.33 If you or your household evacuated, how long did you stay at your destination?

time

Q.34 If you or your household evacuated, when did you return home?

time

Q.35 If you or your household evacuated, who told you that it was safe to return home? (circle all that apply)

local police

state police

fire department

sheriff's department

television

radio national guard

neighbor or friend

Phillips County Office of Emergency Services

co-worker

family member or other relative

other, please specify 
Q.36 If you or your household evacuated, what did you do after you returned home? (circle all that apply)

opened windows and doors took care of animals

called relatives /friends

listened to radio/ television other, please specify washed household items took shower/bath

nothing special

This section is for people who sheltered-in-place. If you did not shelter, please skip the questions 37 through 45 and go to Question 46.

Q.37 If you or your household sheltered, what statement below best describes what you were told about sheltering? (circle only one)

heard no warning to shelter in place

heard a warning, but not told to shelter in place

warned to shelter-in-place, but not told how to do it

warned to shelter-in-place and given general instructions

warned to shelter-in-place and given precise instructions

other (please specify)

Q.38 If you or your household sheltered -- Please circle those reasons below that applied to your household. (circle all that apply)

Situation seemed dangerous

To protect children

To protect pregnancy

Because the authorities told us to stay inside

Pressure from someone outside the family

No place to go so stayed inside

Don't know

Other, please specify

Q.39 If you or your household sheltered, what room(s) did you shelter in? (circle all that apply)

living room

bedroom

kitchen

basement

bathroom

other, please specify

Q.40 If you or your household sheltered, which of the following did you do when you sheltered? (circle all that apply)

closed doors

closed windows

turned off heating/cooling

other, please specify put towels across doorways

taped windows and doors 
Q.41 If you or your household sheltered, what did you do with your animals? (circle all that apply)

took them inside home

put them into an outside structure

left them outside

other, please specify

Q.42 If you or your household sheltered, how much time did you spend getting household members inside and the doors and windows shut?

time

Q.43 If you or your household sheltered, how long did you stay inside?

time

Q.44 If you or your household sheltered, who told you it was safe to stop sheltering?

(circle all that apply)

local police
state police
fire department
sheriff's department
television
radio

national guard neighbor or friend

Phillips County Office of Emergency Services co-worker family member or other relative other, please specify

Q.45 If you or your household sheltered, what did you do after you finished sheltering? (circle all that apply)

opened windows and doors

took care of animals

called relatives /friends

listened to radio/ television

other, please specify washed household items

took shower/bath

nothing special

To understand how people react to an emergency, this section asks you about yourself.

Q.46 How safe did you feel during the accident? (circle only one) very safe somewhat safe somewhat unsafe very unsafe

Q.47 Today, are any of your normal activities changed because of the accident? YES NO

If YES, has the change been: (circle only one) substantial moderate minimal 
Q.48 What was your age at your last birthday? (circle only one)

Under 18

18-24

25-34
$35-44$

$45-54$

$55-65$

over 65

Q.49 Are you male or female?
Male
Female

Q.50 What best describes your racial or ethnic background?

Q.51 At the time of the fire at the chemical plant, what was your marital status? (circle only one)
single
married divorced
separated
widowed
other

Q.52 At the time of the fire at the chemical plant, please indicate in which of the following categories your total family income for last year would fall? (circle only one)
Under $\$ 8,000$
$\$ 8,000$ to $\$ 10,000$
$\$ 11,000$ to $\$ 20,000$
$\$ 21,000$ to $\$ 30,000$
$\$ 31,000$ to $\$ 40,000$
$\$ 41,000$ to $\$ 50,000$
Over $\$ 50,000$

Q.53 At the time of the fire at the chemical plant, what was the occupation of the chief wage earner of the household?

What was the occupation of second wage earner?

Q.54 What would you do differently if a similar situation at the chemical plant occurred again?

Thank you for taking the time to complete the survey. Please place the questionnaire in the envelope provided and mail it to us. If you want to fax the survey, please fax to (423) $574-5938$ in care of: 


\section{Barbara Vogt, Project Manager}

Oak Ridge National Laboratory

Bldg. 4500N MS 6190

Oak Ridge TN 37831

If you want a copy of the report, please print your name and address below.

Name

Address 
APPENDIX C: COPY OF LETTER REPORT SENT TO RESPONDENTS 


\section{Behavioral Survey from Explosion at Chemical Packaging Plant West Helena, Arkansas, Thursday May 8, 1997}

\section{Dear Respondent:}

Thank you for answering the questions on the survey about the fire and explosion at the BPS chemical packaging plant last May. Your answers and comments will help emergency managers better understand how people respond to emergencies involving chemicals, and how warnings and other procedures can help protect people in the future. This letter describes what we have initially learned from the study. We had a $63 \%$ response to the survey (157 returned) and 125 surveys contained enough information to use for these findings.

\section{Did we ask the right people?}

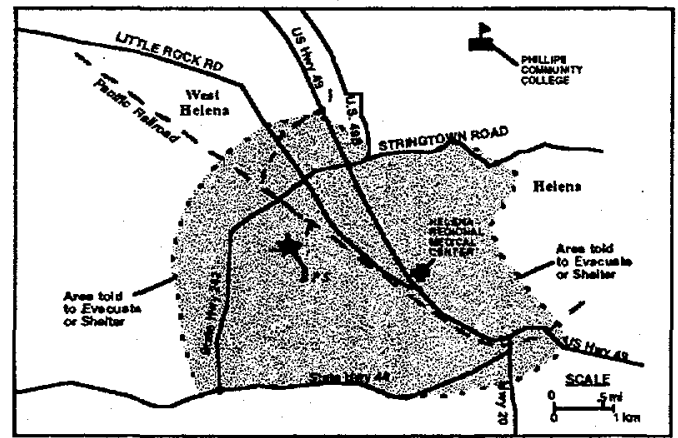

Map Showing Plant Location. Source: H. Hardee, University of Tennessee
Sending the questionnaires to people who were in the hazard area at the time of the accident is very important in a mail survey. With help from your emergency operations officials, we obtained the names of streets in the evacuation and the shelter-in-place zones. More than half (54\%) of those who filled out the survey lived within one mile of the plant. Only 14 people (11\%) lived more than 3 miles from the plant.

Almost everyone who answered the survey- $81 \%$ of the respondents-reported smelling a foul odor or seeing black smoke. Wind direction was important to many people in deciding what to do. Those close to the plant but upwind did not sense any danger from the fire while those downwind were more likely to feel danger and to leave their homes. 


\section{How were people warned?}

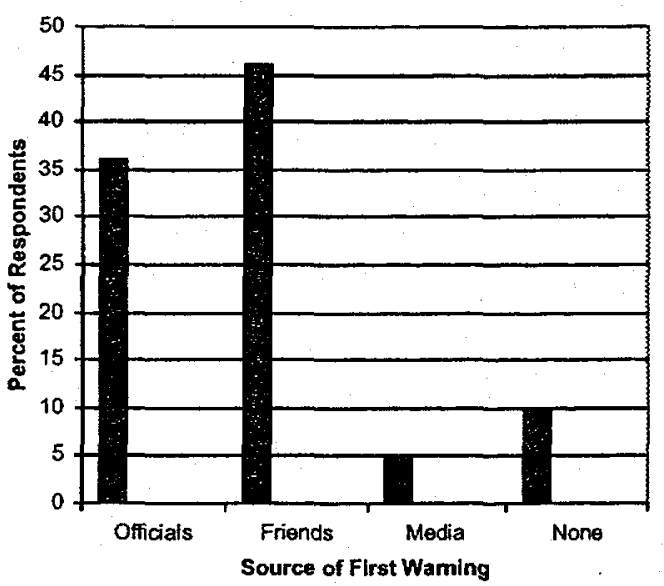

The first official warnings came from a local radio station (KFFA) used to broadcast emergency messages and from deputies going door to door telling people to leave. Past research has shown that neighbors, friends, and other family members often warn people informally before people receive a warning from authorities. This was also true in this study. Almost $46 \%$ said the first warning came from someone they knew, such as neighbors, friends, family, or coworkers. Another $36 \%$ reporting their first warning came from authorities. Some people never heard any warnings and learned of the accident when they tried to return home.

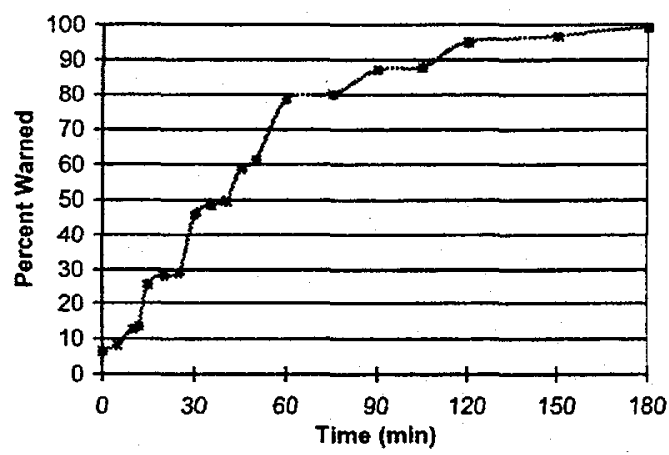

\section{What time did people learn about the} release?

Almost three-fourths (74\%) learned about the release within one hour of the accident. Almost two-thirds of the respondents who heard a warning totally believed the warning was true.

\section{What was people's best source of information during the event?}

We found that half of those people who received warnings about the accident said the media-especially television reportswas their best source of information. Another $26 \%$ said talking with others-such as friends, neighbors, relatives-was their best source of information. 


\section{Did people think they were in danger?}

People understood why they were being asked to evacuate or shelter. Forty-two percent of the people who received warnings thought the chemical cloud would reach their area within 10 minutes.

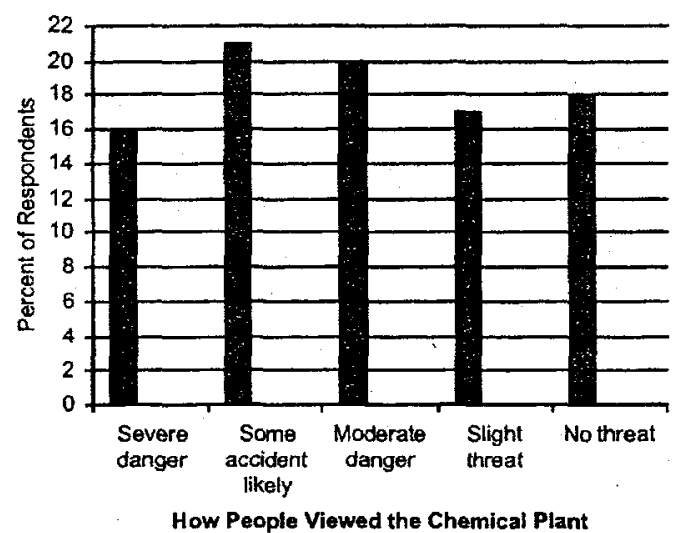

How People Viewed the Chemical Plant

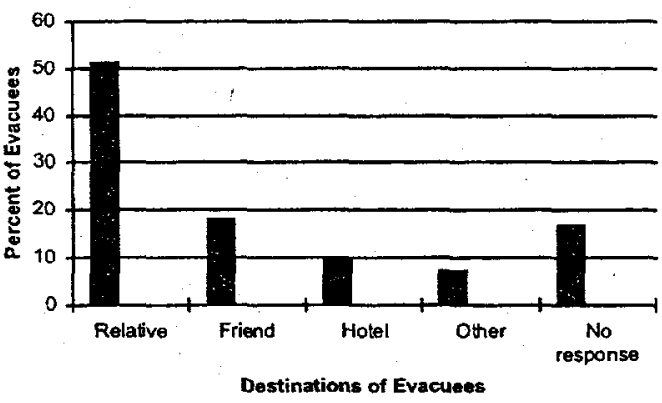

About one-third of the respondents knew before the accident that chemicals were stored at the plant. The survey found that people were about evenly divided as to the danger from the stored chemicals. About $16 \%$ of the people that answered the question thought the chemical danger before the accident was severe, $21 \%$ thought some accident was likely, $20 \%$ thought there was moderate danger, $17 \%$ thought there was a slight threat, and $18 \%$ thought there was no threat.

Two-thirds $(66 \%)$ of the respondents had lived in their residences for more than 10 years, suggesting most people knew the area well. Several respondents noted that there are other chemical plants in the industrial park and that anyone living in the area would be aware of the chemical plants.

\section{Where did people go who evacuated?}

About two-thirds of the evacuees went to a home of a friend or relative when they evacuated. Ten percent $(10 \%)$ went to a hotel (including a casino) or motel but only one person reported visiting a public shelter. 

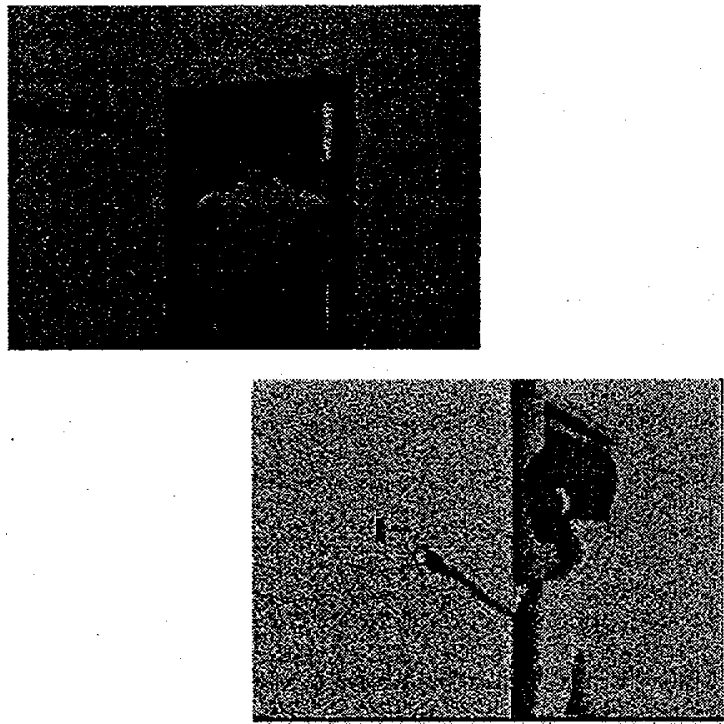

What did people who sheltered in place do?

The information on those that sheltered in place may not be representative of all people who sheltered because only few people (12) reported sheltering. Seventy-five percent $(75 \%)$ of those that sheltered did so because the situation seemed dangerous or because authorities told them to stay indoors. Others had no place to go so stayed inside, some sheltered to protect children, and others sheltered because they were pressured by someone outside the immediate family to shelter.

People who sheltered generally

- closed doors and windows,

- turned off heating and cooling systems, and/or

- stayed in residence overnight.

Only two people taped windows and doors or put towels across doonways to help protect themselves.

Most people learned it was safe to stop sheltering from local police or from a local television or radio broadcast. No one reported having a family member or coworker tell them. Four people reported a neighbor told them it was safe to stop sheltering. 
What did people do after they stopped sheltering?

Generally people did what authorities suggest after sheltering in place. People cleared the air in their homes by opening doors and windows, some took care of animals, and others called relatives and friends. Ten people reported listening to the media, four washed household items, and showered or bathed while others reported not doing anything special.

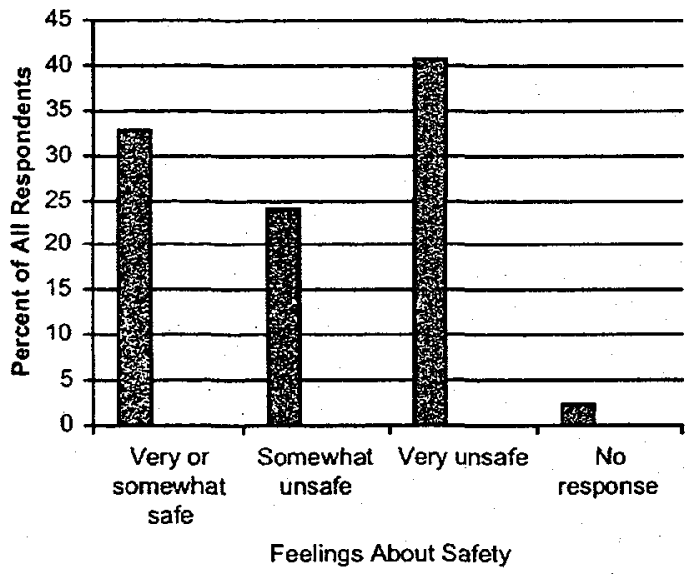

\section{Did people feel safe during the event?}

About one-third $(33 \%)$ of the all respondents felt very or somewhat safe during the event. Others $(41 \%)$ felt very unsafe and others felt somewhat unsafe $(24 \%)$. Similarly $36 \%$ reported feeling their normal daily activities have been changed since the incident, but over $56 \%$ reported no change at all in their daily activities. For those that felt their daily activities had been changed, only twelve reported the change had been substantial while twenty reported the change as moderate or minimal. 


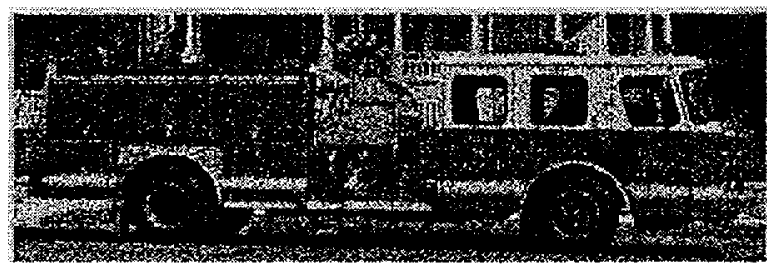

What are the implications from the study for helping protect people in the future?

It would appear that what people did was based on what they thought they were told to do. The problem is that not everyone understood exactly what they were supposed to do, and if they were uncertain, they usually evacuated from their residence. Results of this survey will be used to improve warnings and instructions in future emergencies.

Investments in community planning through public/private partnerships can help reduce a community's vulnerability to industrial accidents-whether accidents occur at a facility or on a highway. Both the Helena and West Helena firefighting departments are in the process of obtaining new equipment to better protect emergency responders in the future. This includes a new pump truck. Some of the donations have come from the BPS company. BPS has also rebuilt the damaged building. More communication links are now in place between the chemical companies and emergency service agencies. Last fall the Phillips County Office of Emergency Services published a citizen's brochure with emergency phone numbers and instructions on what to do during an evacuation and how to shelter in place. A copy is enclosed with this letter. 
No one can predict when an accident will happen, but how people and officials respond makes a big difference in handling an emergency. Advising people to evacuate and telling other people close by to shelter may not be successful if people don't understand the reasons for the different recommendations. People need to know what the hazards are in their community and what to do if asked to stay at home and shelter and when told to evacuate. This cannot wait until an accident. Public education programs in schools, through social or civic organizations, or in church groups can help spread information.

We appreciate the efforts of the Emergency Management Services and other organizations in Phillips County for their help in this study. If you have any further comments, feel free to write us. Again, thank you for your help.

Sincerely,

John $\mathrm{H}$. Sorensen

Research Staff
Barbara M. Vogt

Research Staff 


\section{DISTRIBUTION}

\section{Internal}

1. G. E. Courville

6-45. J. H. Sorensen

2. T. R. Curlee

3. H. Hardee

4. R. R. Lee

5. R. B. Shelton

46-85. B. M. Vogt

86. Central Research Library

87. Lab Records-RC

\section{External}

88. Lilia A. Abron, President, PEER Consultants, P.C., 1460 Gulf Blvd., $11^{\text {th }}$ Floor, Clearwater, FL 34630

89. Dr. Susan L. Cutter, Professor and Chair, Director, Hazards Research Lab, Department of Geography, University of South Caroline, Columbia, South Carolina 29208

90. Randy Devault, U.S. Department of Energy, Oak Ridge, TN

91. Thomas E. Drabek, Professor, Department of Sociology, University of Denver, Denver, CO 80208-0209

92. Dr. Stephen G. Hildebrand, Director, Environmental Sciences Division, Oak Ridge National Laboratory, Post Office Box 2008, Oak Ridge, Tennessee 37831-6037

93. Dr. Dennis Mileti, Natural Hazards Center, Campus Box 482, University of Colorado, Boulder, CO 80309-0482

94. P. Richard Rittlemann, FAIA, Executive Vice President, Burt Hill Kosar Rittleman Associates, 400 Morgan Center, Butler, PA 16001-5977

95. Susan F. Tierney, The Economic Resource Group, Inc., One Mifflin Place, Cambridge, MA 02138

96. C. Michael Walton, Ernest H. Cockrell Centennial Chair In Engineering and Chairman, Department of Civil Engineering, University of Texas at Austin, Austin, TX 78712-1076

97-98. Office of Assistant Manager of Energy \& Development, P.O. Box 2001, Oak Ridge, TN 37831-6269

99-100. Office of Scientific and Technical Information, P.O. Box 62, Oak Ridge, TN 37831

101. ORNL Site Manager, U.S. Department of Energy, Oak Ridge National Laboratory, P.O. Box 2008, Oak Ridge, TN 37831-6269 